WSRC-RP-92-756

\title{
ANALYSIS OF K-AREA CORE SAMPLES FOR K-AREA FORMATION STABILIZATION WORK (U)
}

by C. A. Langton

Westinghouse Savainah River Company

WSRC-RP--92-756

Savannah River Site

Aiken, South Carolina 29808

DE93 003381

This paper was prepared in connection with work done under Contract No. DE-AC09-89SR18035 with the U. S. Department of Energy. By acceptance of this paper, the publisher and/or recipient acknowledges the U.S. Government's right to retain a nonexclusive, royalty-free license in and to any copyright covering this paper, along with the right to reproduce and to authorize others to reproduce all or part of the copyrighted paper. 


\section{DISCLAIMER}

This report was prepared as an account of work sponsored by an agency of the United States Government. Neither the United States Government nor any agency thereof, nor any of their employees, makes any warranty, express or implied, or assumes any legal liability or responsibility for the accuracy, completeness, or usefulness of any information, apparatus, product, or process disclosed, or represents that its use would not infringe privately owned rights. Reference herein to any specific commercial product, process, or service by trade name, trademark, manufacturer, or otherwise does not necessarily constitute or imply its endorsement, recommendation, or favoring by the United States Government or any agency thereof. The view's and opinions of authors expressed herein do not necessarily state or reflect those of the United States Government or any agency thereof.

This report has been reproduced directly from the best available copy.

Available to DOE and DOE contractors from the Office of Scientific and Technical Information, P.O. Box 62, Oak Ridge, TN 37831; prices available from (615) 576-8401, FTS 626-8401.

Available to the public from the National Technical Information Service, U.S. Department of Commerce, 5285 Port Royal Rd., Springfield, VA 22161. 
WESTINGHOUSE SAVANNAH RIVER COMPANY

SAVANNAH RIVER TECHNOLOGY CENTER

\author{
WSRC-RP $-92-756$ \\ Keywords: K-Area Core \\ Foundation \\ Stabilization
}

May 27, 1992

CC: PAUL BROWN, Bechtel SF BILL GODWIN, Bechtel SF FRANK SIMS, Bechtel SF W.L. TAMOSAITIS, 773-A SRL Records (4)

TO: W. E. STEVENS, 773-43A

EROM: C. A. LANGTON, 773-43A C

ANAIYSIS OF K-AREA CORE SAMRLES FOR K-AREA FORMATION STABILIZATION WORK (U)

\title{
SUMMARY
}

Foundation stabilization work in $\mathrm{K}$-Area has been recently completed by Bechtel Inc. This effort involved pumping cement and cement-sand grout into unconsolidated sediments under K-Area. Subsequent to stabilization, core samples were collected to document the extent of grout flow in the area. Samples of this core were examined by SRTC personnel in support of the grouting program at the request of Bechtel personnel. This report summarizes the results of the SRTC study.

\section{QBJECTIVE}

The objectives of this study were to differentiate between grout emplaced by the Army Corps of Engineers as part of an earlier attempt to stabilize the area in the 1950's and grout emplaced by KASS within the last year. In addition samples were examined for evidence of multiple grout injections in an attempt to determine how the stabilizing material filled the 
W'SRC-FlP $-92-756$

Page 2

May 27, 1992

void spaces in the unconsolidated sediments. Interfacial regions between grout and the formation were examined. Samples were also evaluated for specific gravity, adsorption, and compressive strength. Porosity was not measured because the range in pore size distribution gave misleading results. porosity was estimated to range between 20-30\% based on specific gravity measurements.

\section{BESUITS AND DISCUSSION}

Field and laboratory sample labeling and field descriptions are listd in Table I. Specific gravity, water absorption and compressive strength results are presented in Tables 2-4, respectively. The spg of all samples was $2.0 \pm 0.1$ except for the apatitic sandstone (spg 2.3) in Core P-2-VSH-2.0 taken from 158-160.2 ft. Water absorption ranged from 5 to 15\%. Right cylinders $41 / 2$ inches long were cut and tested for compressive strength in an Instron. Values ranged from 704 to 2855 psi.

$X$-Ray diffraction was used to differentiate between 40 year old grout and one year old material. Ettringite, a calcium aluminum sulfate hydrate, and hydrogarnet were indicative of the 40 year old Army Corps of Engineers (COE) grout. Portlandite (i.e. calcium hydioxide and calcium silicate hydate gel) were characteristic of the one year old grout. Calcite was detected in all of the grout samples except P-7VSH-19.0 (CL-14). Consequently even one year appears to provide sufficjerst time for some of the $\mathrm{Ca}(\mathrm{OH}) 2$ to carbonate to calcite. Results are summarized in Table $V$. $x$-Ray patterns are included in Appendix V.

$\mathrm{X}$-Ray diffraction data indicate that the sediment contains montmorillonite clay and quartz sand. Samples from P-2-VSH2.0 at 158-160.2 ft were identified as apatitic sandstone. Magnification of the samples up to $30 \mathrm{x}$ indicates that some of the quartz grains contain oxidized iron sulfide which results in orange (rust) staining. See Appendix II. A few ilmenite, black sand, grains were also detected.

Layering of the core samples was documented on a scale of centimeters to $0.1 \mathrm{~mm}$. This is illustrated in 1) Appendix I which contains the macroscopic photographs of each core 2) binocular microscope photos in Appendix II, and 3) scanning electron microscope images in Appendix III. For example, core P-2-VSH-3.0 at 122-127 ft, (CL-7) ws identified as COE sanded grout containing small pieces of apatitic sandstone. Sample CL-8 taken from Core P-2-VSH-3.0 at 125-126.3 ft, showed descrete interfaces between clayey sandstone and cement grout (with some sand). Sample CL-11 taken from core $\mathrm{P}-2-\mathrm{VSH}-3.0$ at 125 to $132 \mathrm{ft}$. shows a thin cement grout layer 
ẂSRC-IP-92-756

Page 3

May 27, 1992

injected into a sandy zone in the formation. Sample CL-14 taken from core $\mathrm{P}-7-\mathrm{VSH}-19.0$ at $129.5-130$ ft contains well consolidated cement grout (with some sand) in contact with what could be a cement stabilized sand formation or sanded grout. CL-15 shows orientation of quartz grains in a layer in sanded grout or stabilized formation.

SEM microscopy also shows interfacial zoning as illustrated in Appendix III. Sample CL-12 taken from core P-2-VSH-4.0 at 122 to 123 ft shows neat cement grout with a few sand grains forming a sharp interface with sanded-cement grout. This suggests that separate injections make up this section of core.

\section{CONCIUSION}

Portlandite and calcium silicate hydrate gel were conclusive in identifying KASS grout. Ettringite and hydergarnet were well crystallized in Army Corps of Engineers grout which is about 40 years old. The absence of portlandite was also indicative of the 40 year old grout.

The sediment examined ranged from unconsolidated sand to sandy clay (montmorillonite). Core P-2-VSH-2.0 at 158-160.2 ft contained zones of apatitic sandstone.

The core samples displayed extensive layering on a macroscopic and microscopic scale. The interfaces between the regions were either sharp contacts or were characterized by alignment of quartz grains.

Samples which were obviously injected grout were CL-1, 2, 3, $11,12,17$, and 18. Several samples including, CL-6, 7, 8, $9,11,14$, and 15 have ambiguous features and could be described as cement + water injected into the formation sand. This interpretation is based on the clear, glassy surfaces of the sand (also found in the sediments) as opposed to the frosted sand surfaces found in the obvious grout samples, such as $C L-17$ and $C L-18$. It is also based on the texture and mineralogy of the samples. However, portions of $\mathrm{Cl}-6,7,8$, $9,11,14$, and 15 also resemble injected sand-cement grout. 

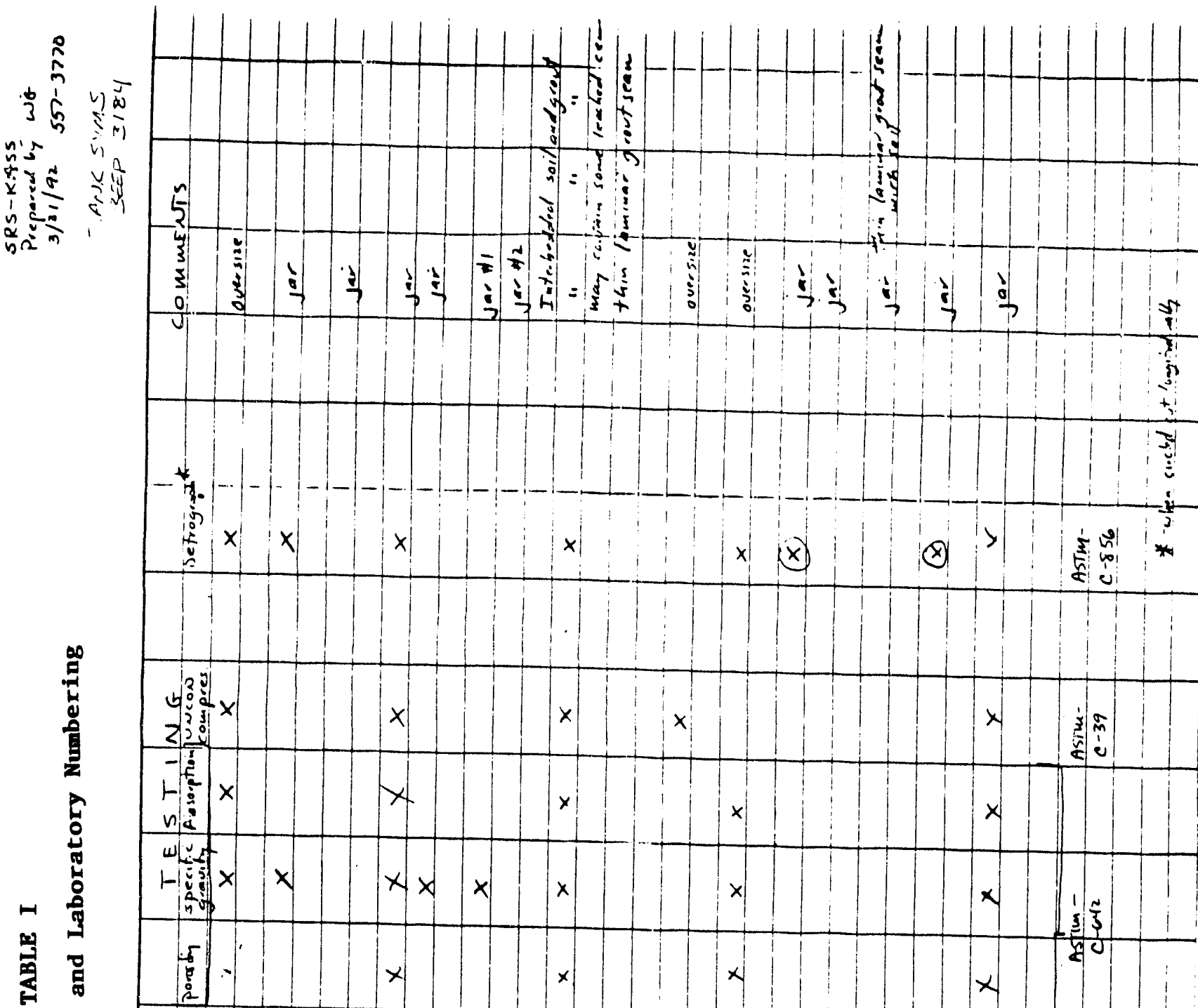

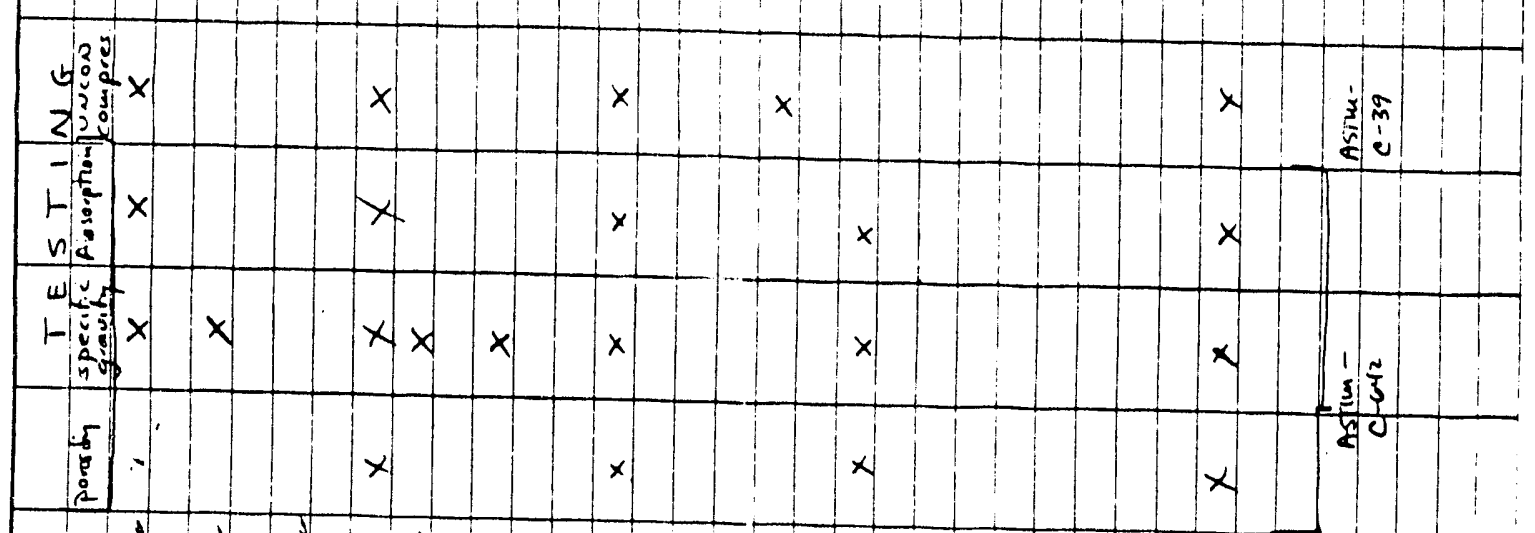

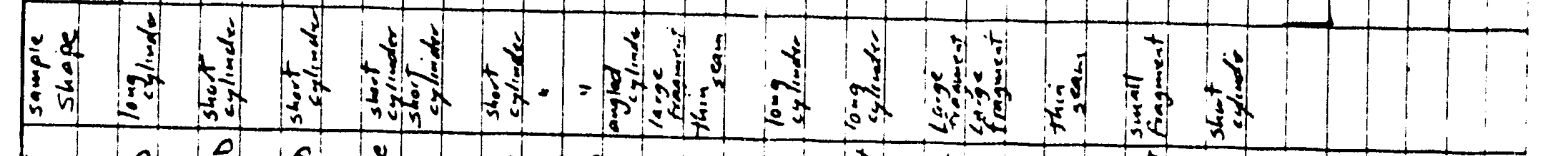

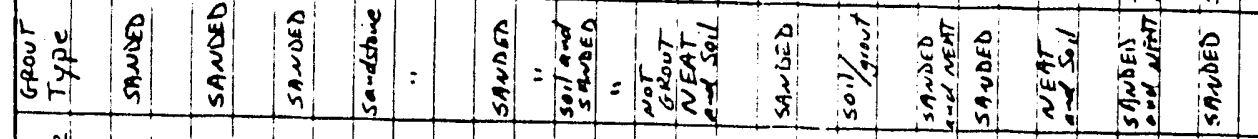

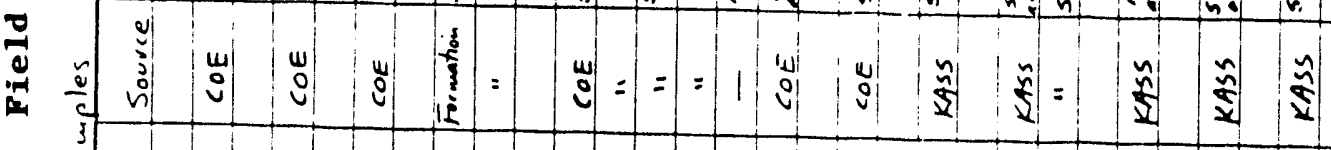

เป

$+$

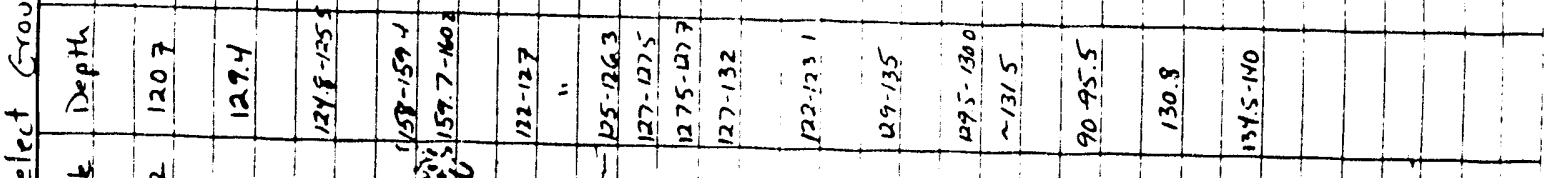

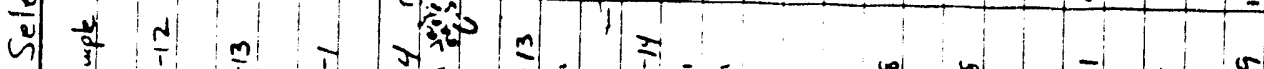

v

3ी

3 ํ.

ง

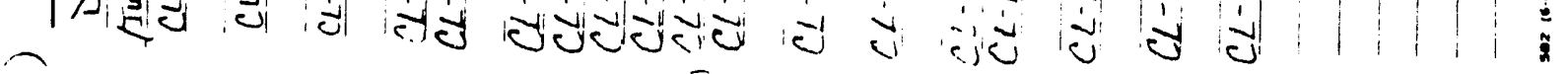




\section{TABLE II}

\section{SPECIEIC GRAVITY OF K-AREA CORE SAMPLES}

\begin{tabular}{|c|c|c|c|c|c|c|c|c|c|}
\hline & \multicolumn{2}{|c|}{$P-2-V S H-1.0$} & \multicolumn{2}{|c|}{$P-2-V S H-2.0$} & \multicolumn{2}{|c|}{$P-2-V S H-3.0$} & \multirow{2}{*}{$\begin{array}{l}\text { V-2- } \\
\text { vsB- } \\
4.0 \\
\mathrm{CI}-12\end{array}$} & \multirow{2}{*}{$\begin{array}{l}P-7- \\
\text { VSB - } \\
17 \\
\text { CI-13 }\end{array}$} & \multirow{2}{*}{$\begin{array}{l}\text { P-7- } \\
\text { VSB- } \\
49.0 \\
C I-18\end{array}$} \\
\hline & CI - I & $C I-2$ & $C I-4$ & $C I-5$ & CL-6 & CL-9 & & & \\
\hline $\begin{array}{l}w t \\
(g)\end{array}$ & 513 & 176 & 363 & 472 & 520 & 370 & 492 & 158 & 336 \\
\hline $\begin{array}{c}\text { volume } \\
\text { (ml) }\end{array}$ & 280 & 90 & 170 & 205 & 260 & 185 & 255 & 80 & 160 \\
\hline $\begin{array}{c}\text { spg } \pm \\
0.1\end{array}$ & 1.9 & 2.0 & 2.1 & 2.3 & 2.0 & 2.0 & 2.0 & 2.0 & 2.1 \\
\hline
\end{tabular}




\section{TABLE III}

\section{ADSORPTION \\ K-AREA CORE SAMPIES}

\begin{tabular}{|l|c|c|c|}
\hline Sample ID & $\begin{array}{c}\text { Initial wt } \\
(g)\end{array}$ & $\begin{array}{c}\text { Final } \\
\text { saturated wt } \\
(g)\end{array}$ & $\begin{array}{c}\text { Water } \\
\text { Adsorption }\end{array}$ \\
\hline$C L-1$ & 513 & 591 & 15 \\
\hline$C L-4$ & 354 & 376 & 6 \\
\hline$C L-9$ & 356 & 375 & 5 \\
\hline$C L-12$ & 488 & 547 & 12 \\
\hline$C L-18$ & 328 & 353 & 7 \\
\hline
\end{tabular}




\section{TABLE IV}

\section{COMPRESSIVE STRENGTH OF \\ K-AREA CORE SAMPLES \\ (psi)}

\begin{tabular}{|l|c|c|c|c|c|}
\hline & $\begin{array}{c}P-2-V S H-1.0 \\
C I-1\end{array}$ & $\begin{array}{c}P-2-V S H-2.0 \\
C L-4\end{array}$ & $\begin{array}{c}P-2-V S H-3.0 \\
C L-9\end{array}$ & $\begin{array}{c}P S-2-V S H-4.0 \\
C L-12\end{array}$ & $\begin{array}{c}P-7-V S H-49.0 \\
C L-18\end{array}$ \\
\hline 1 & 2092 & 730 & 704 & 1802 & 2855 \\
\hline 2 & 1859 & - & - & - & - \\
\hline AVE & 1976 & 730 & 704 & 1802 & 2855 \\
\hline
\end{tabular}




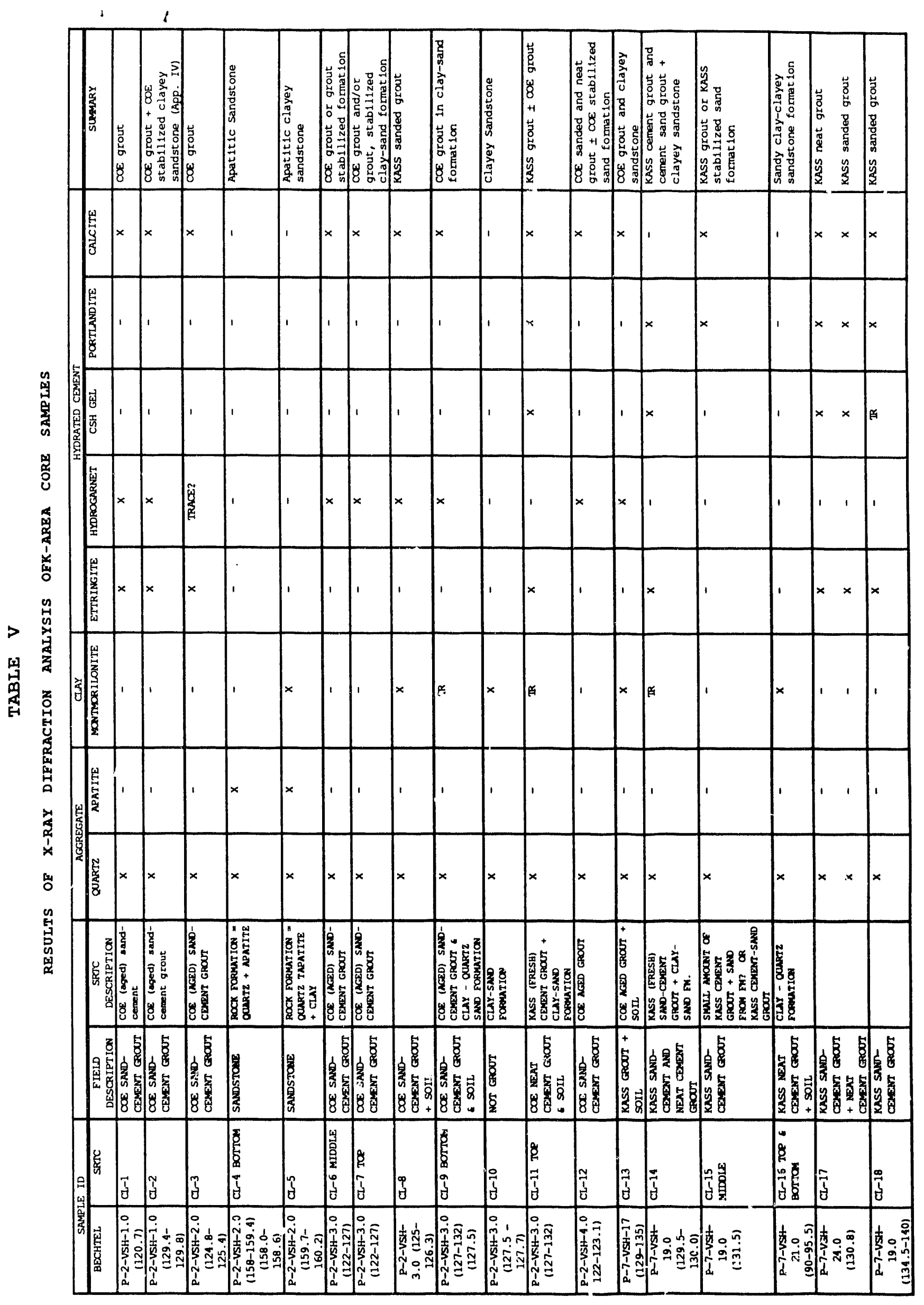


APPENDIX I

Photographs of R-Area Core Samples with Sample Labels 

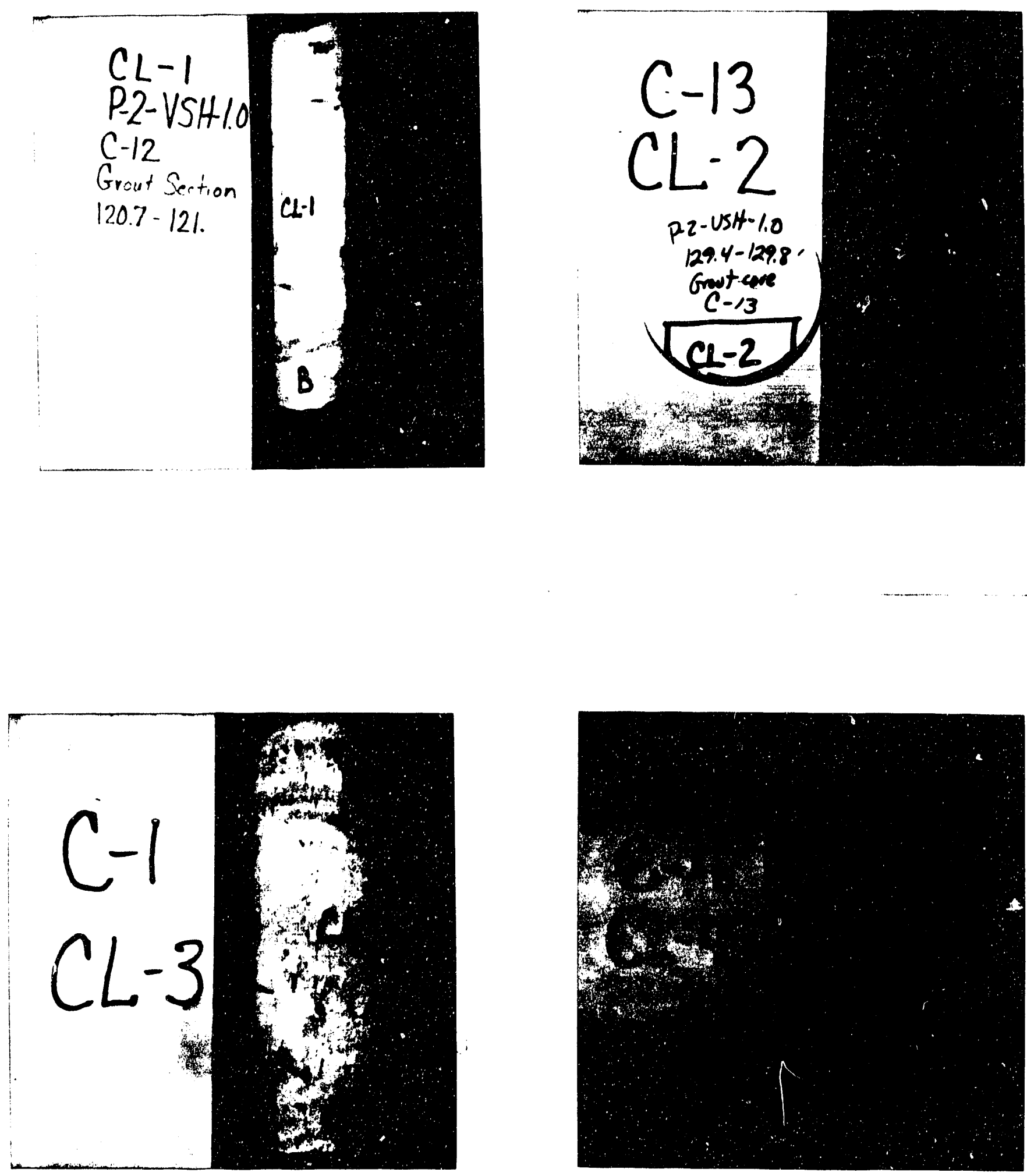

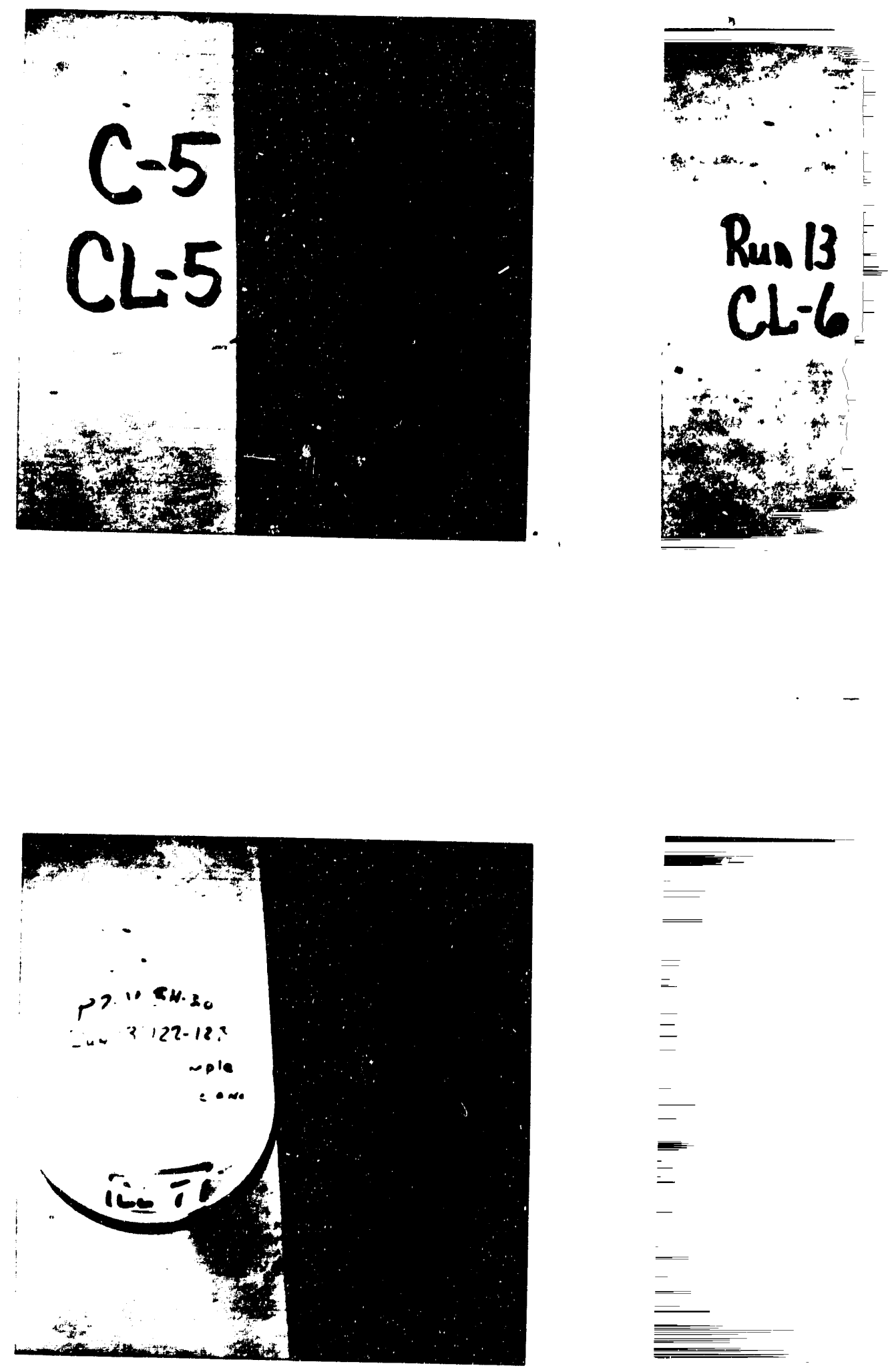


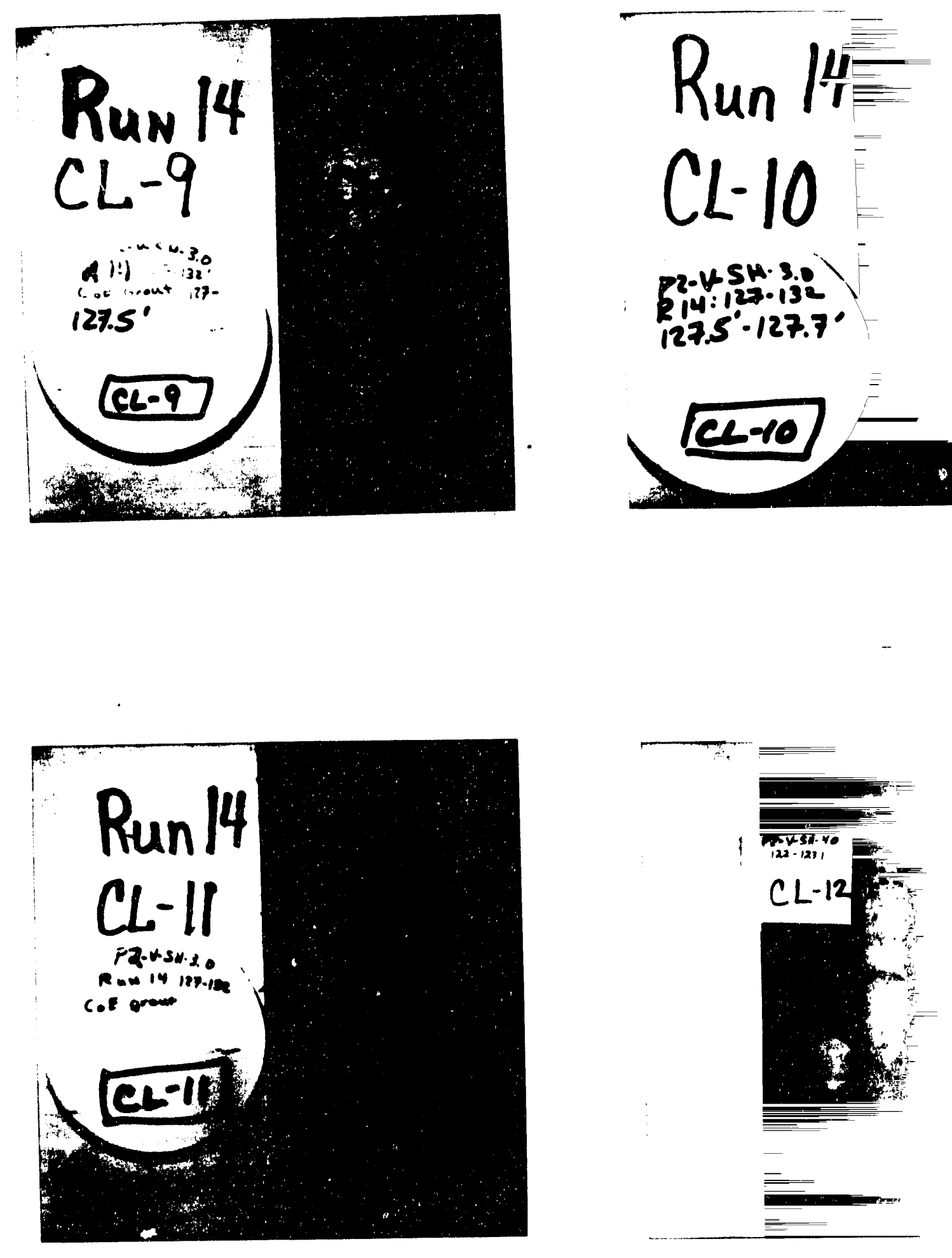



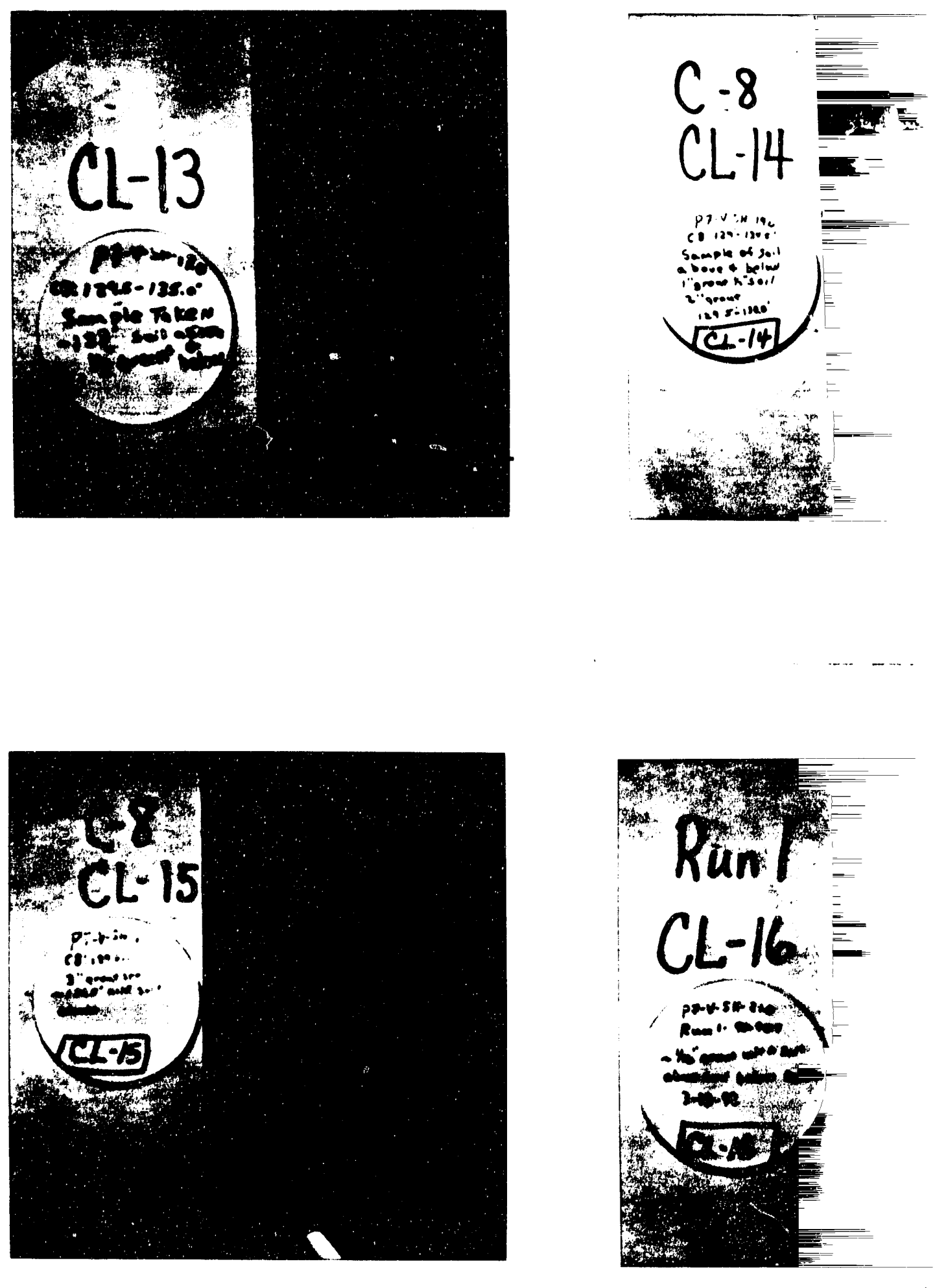

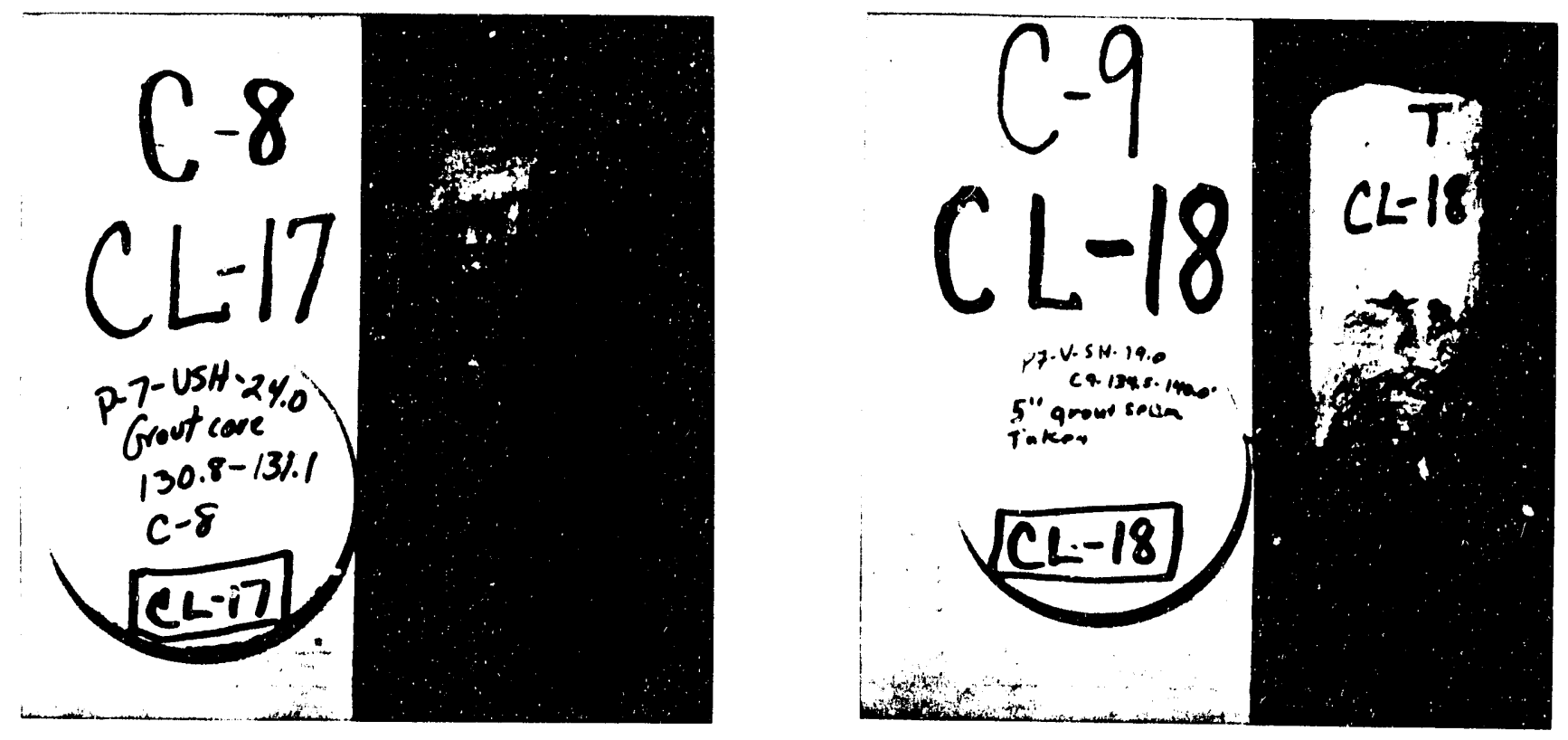
APPENDIX II

Binoculax Microscope Photographs of R-Arex Samples 


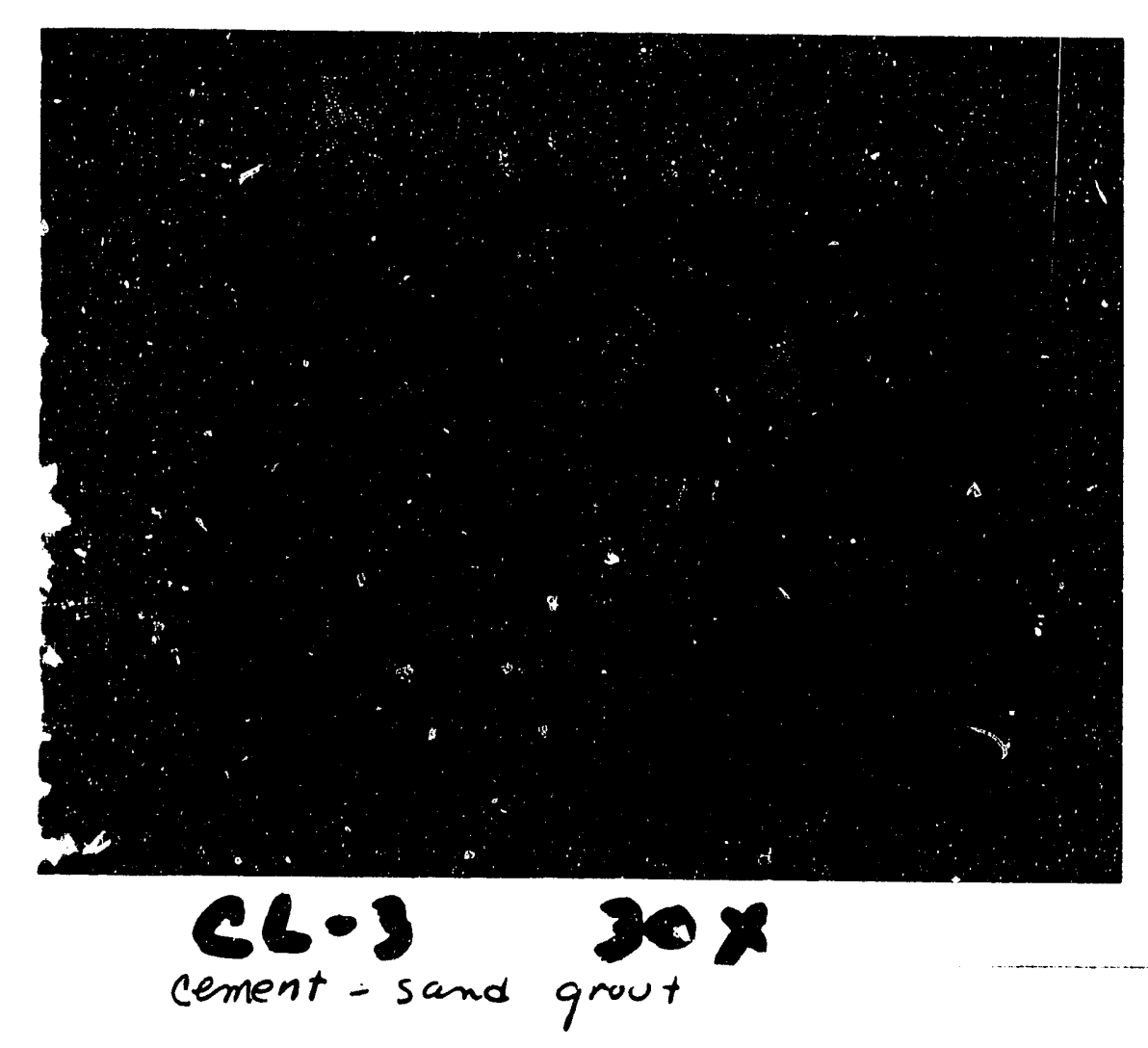

Ce-4 $30 x$

apatitic sandstrme wich clay

P. II 

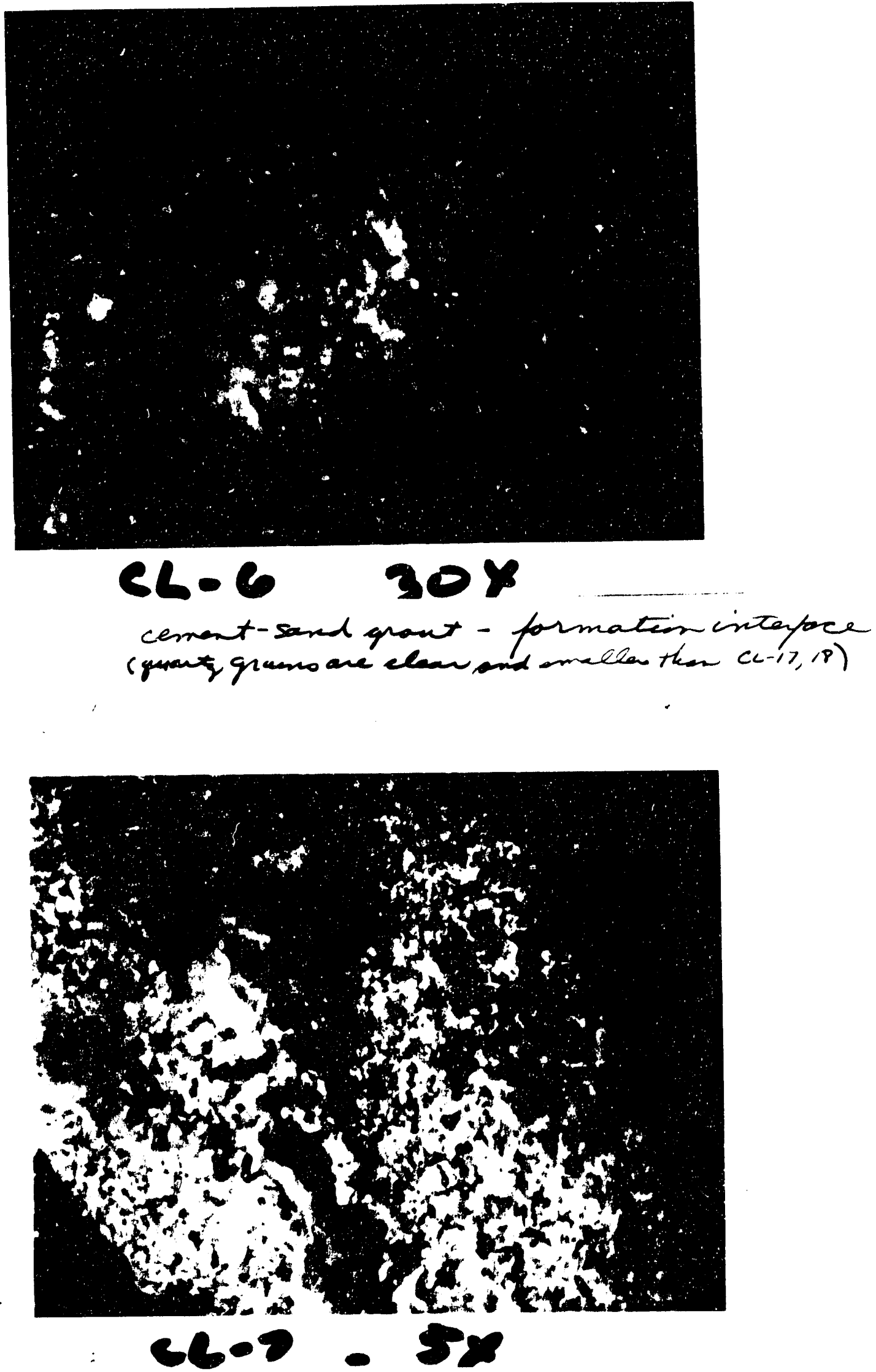

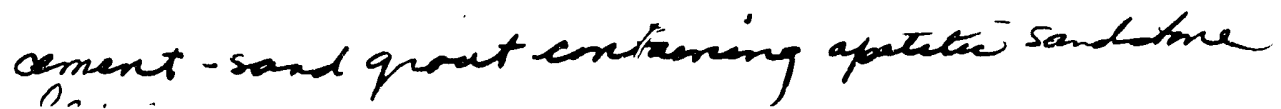




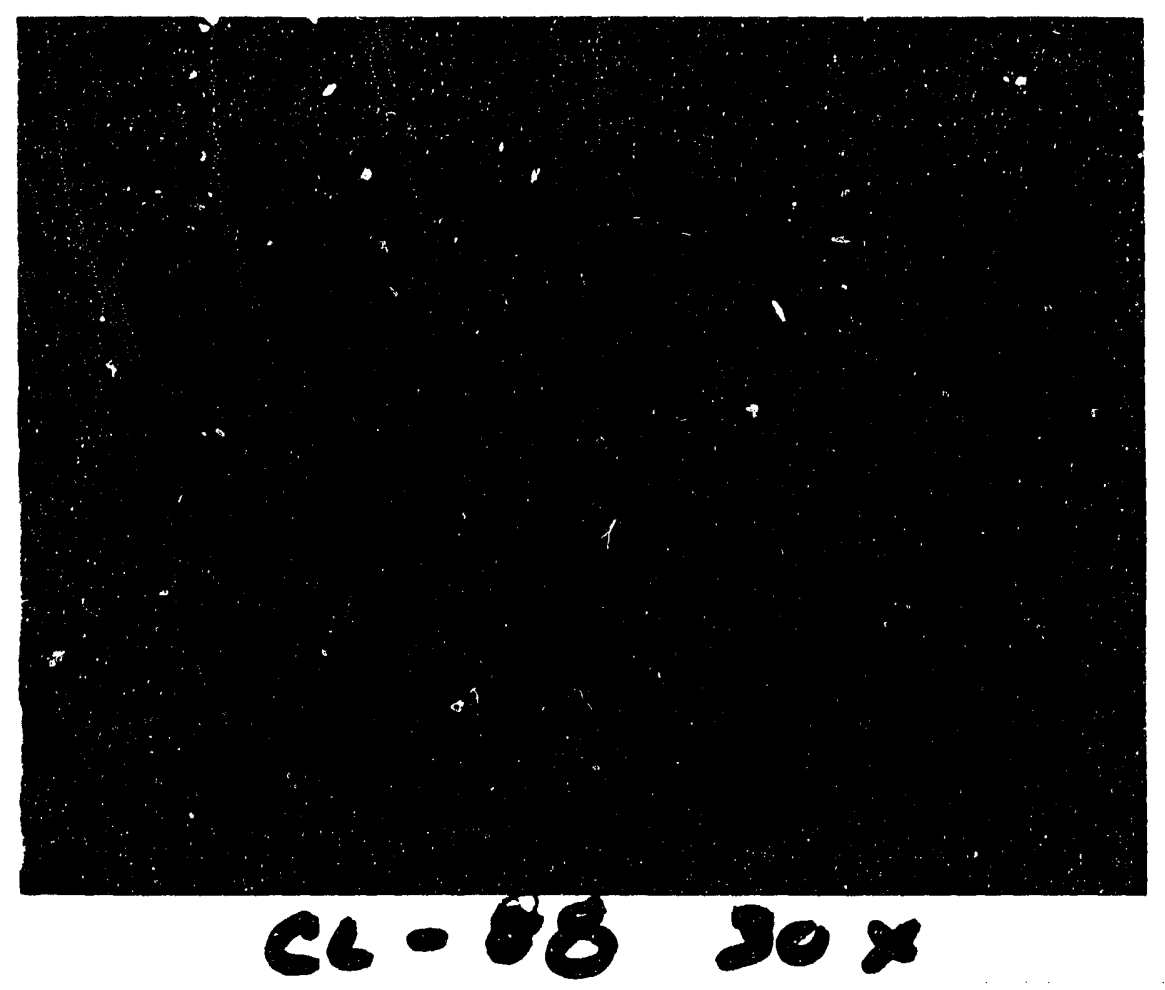

cement rech grout - exdy clay formation intagere

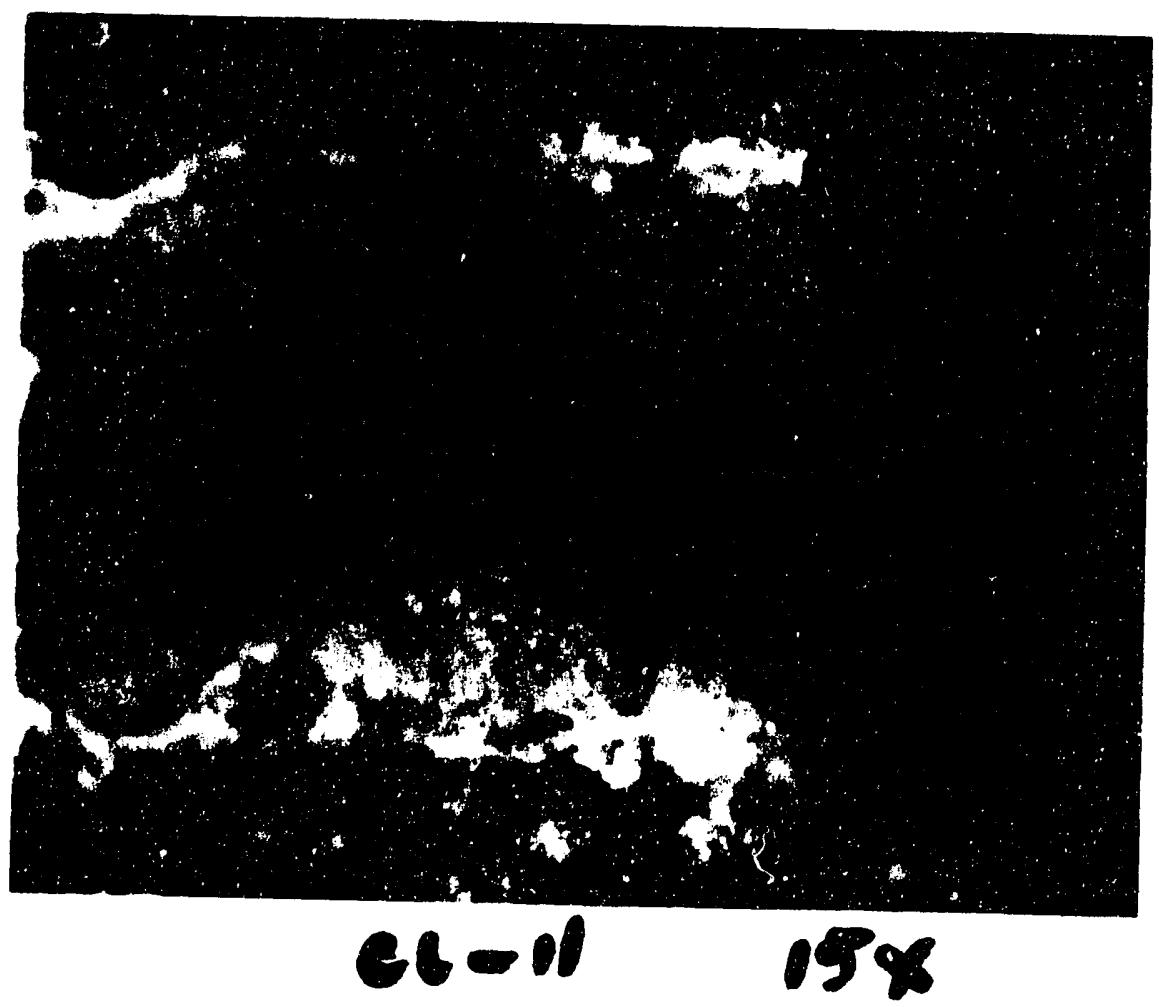

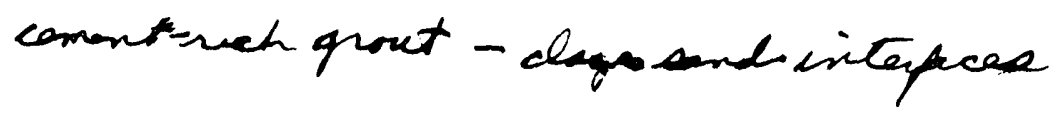




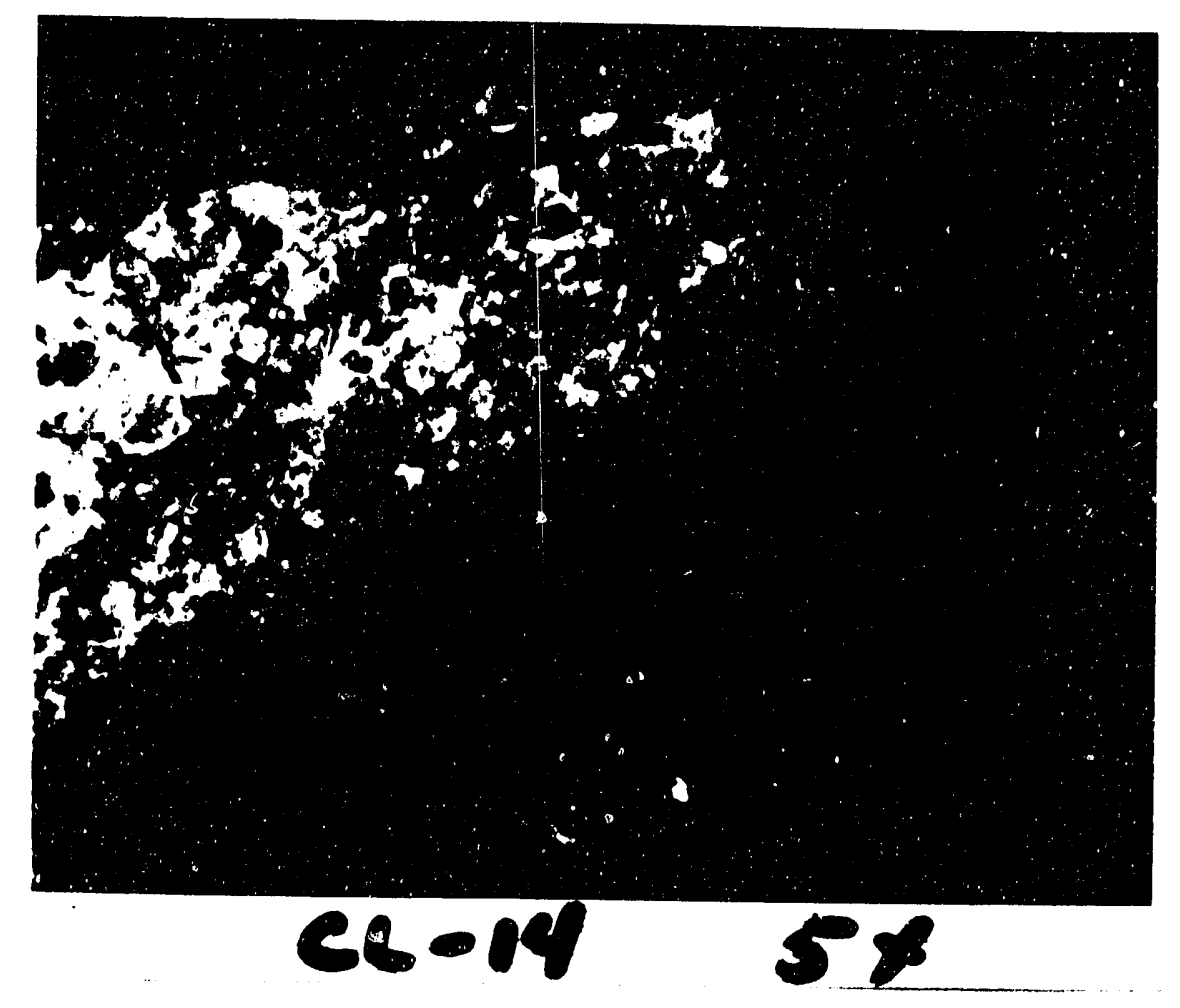

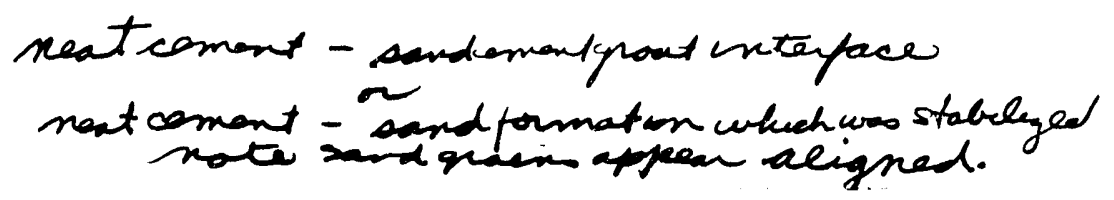

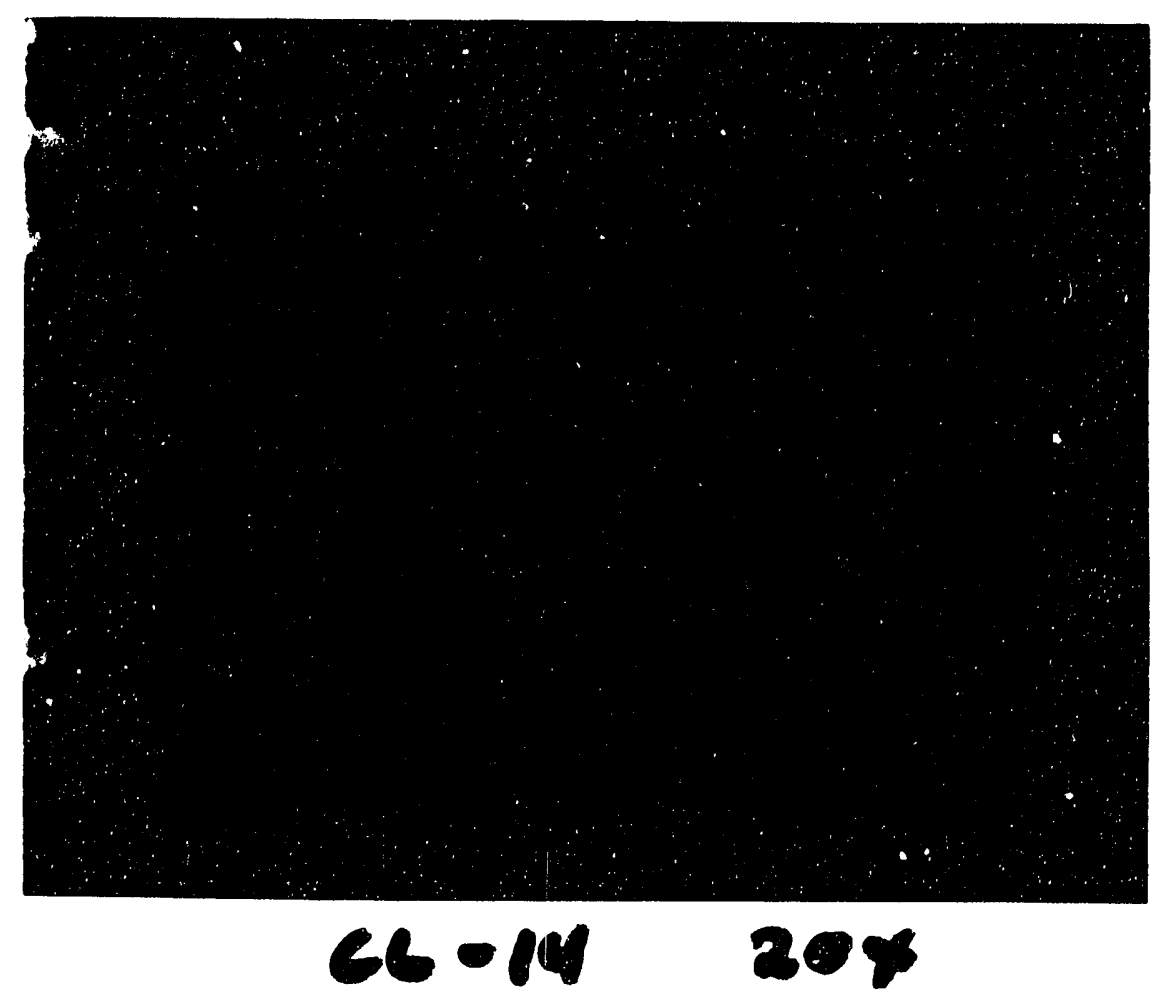



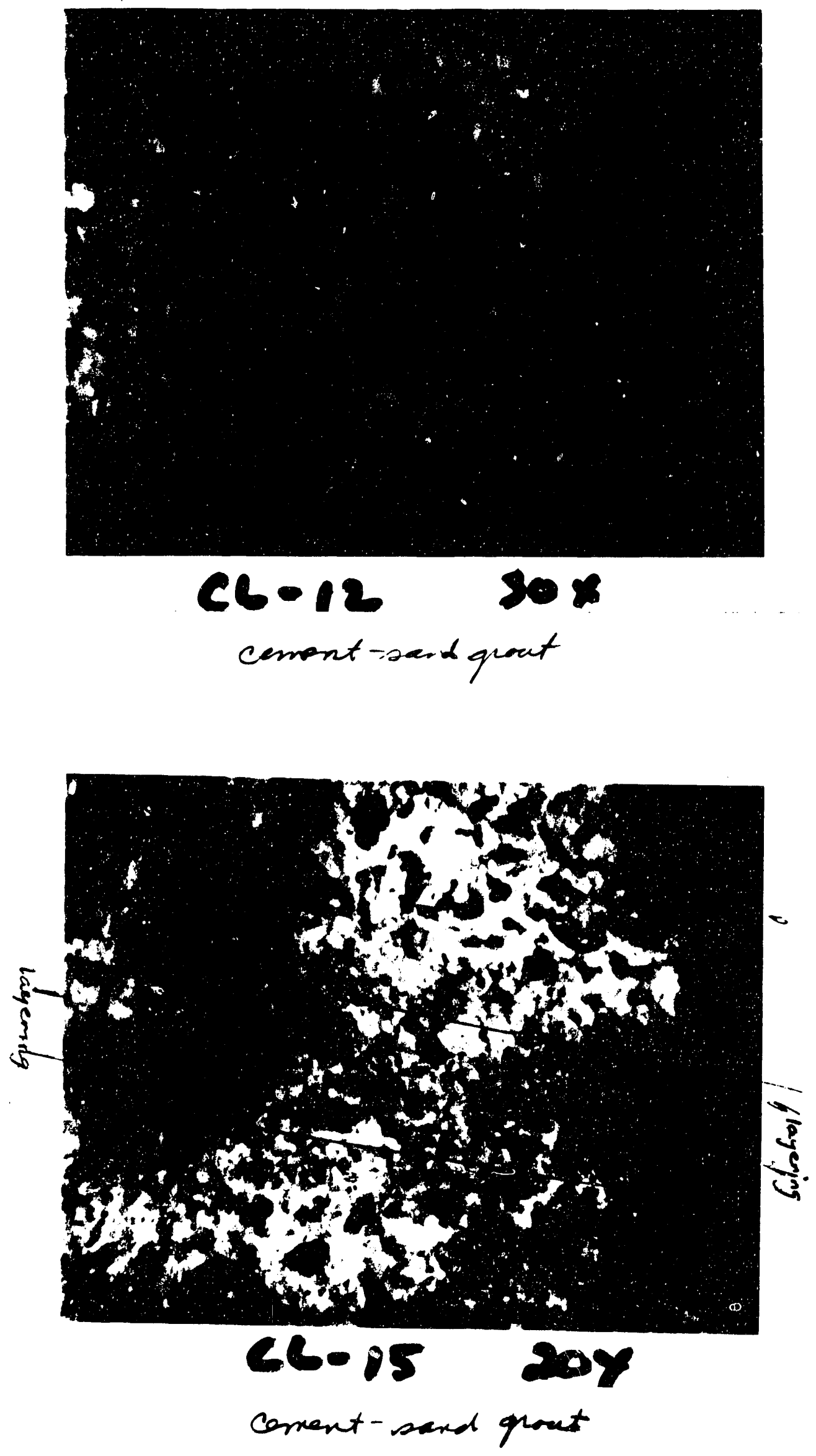

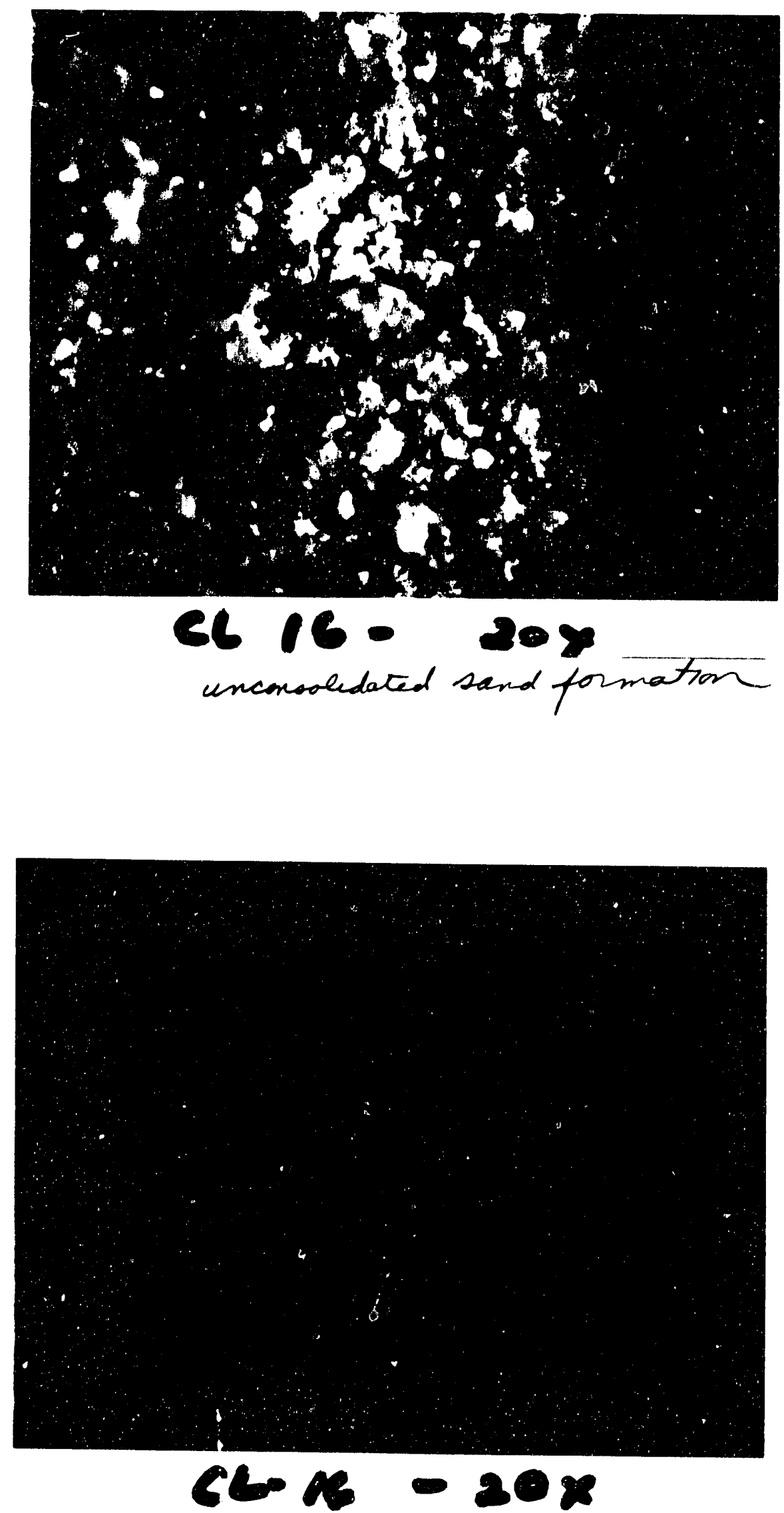

un stavery from sudzed esin sagfele grains in quaity sand. 

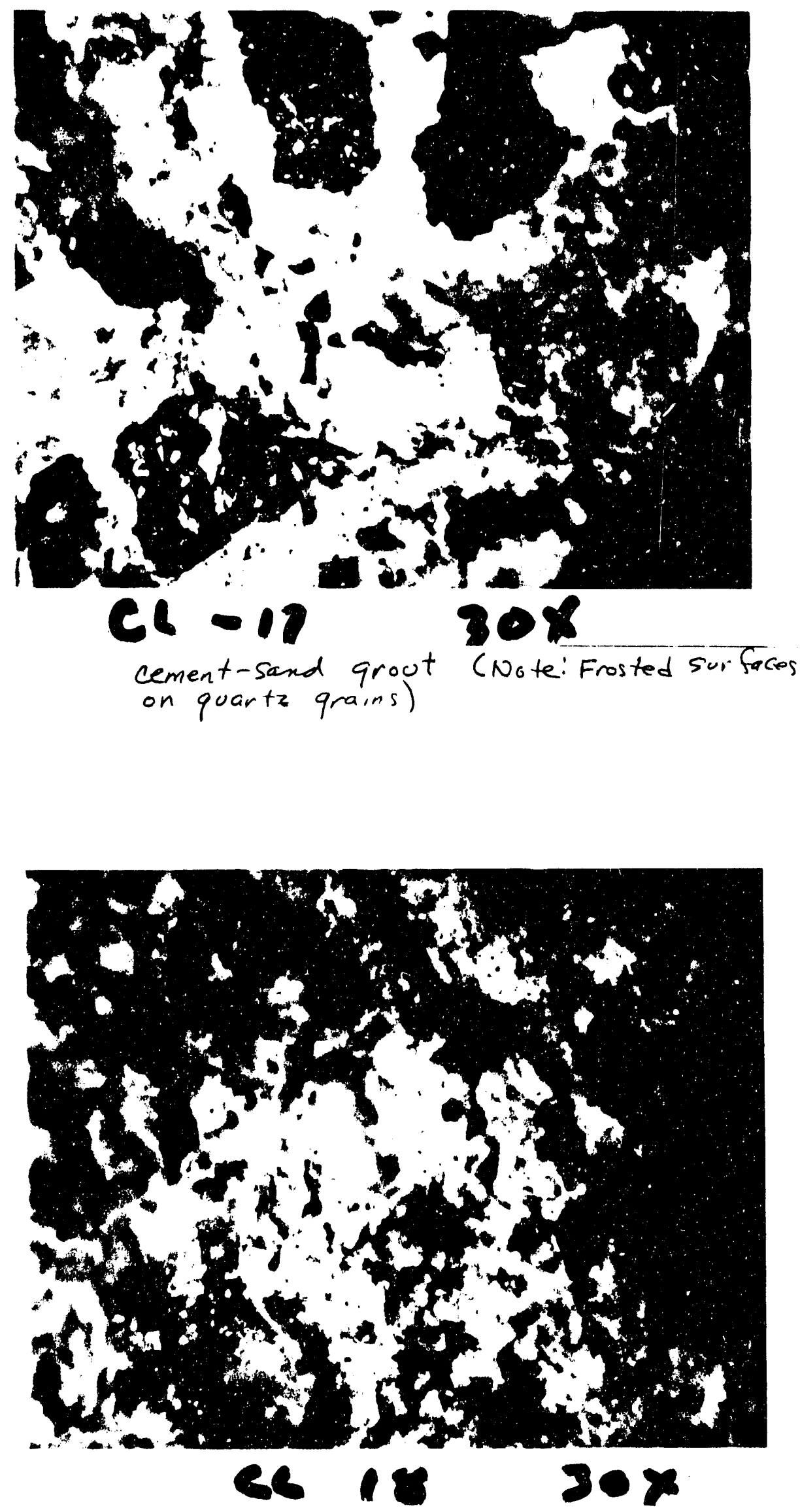

Cement-sand grout. 


\begin{abstract}
APPENDIX III
Interfacial Regions in Scanning Eelectron

Microscope Photographs of R-Area Core Samples
\end{abstract}




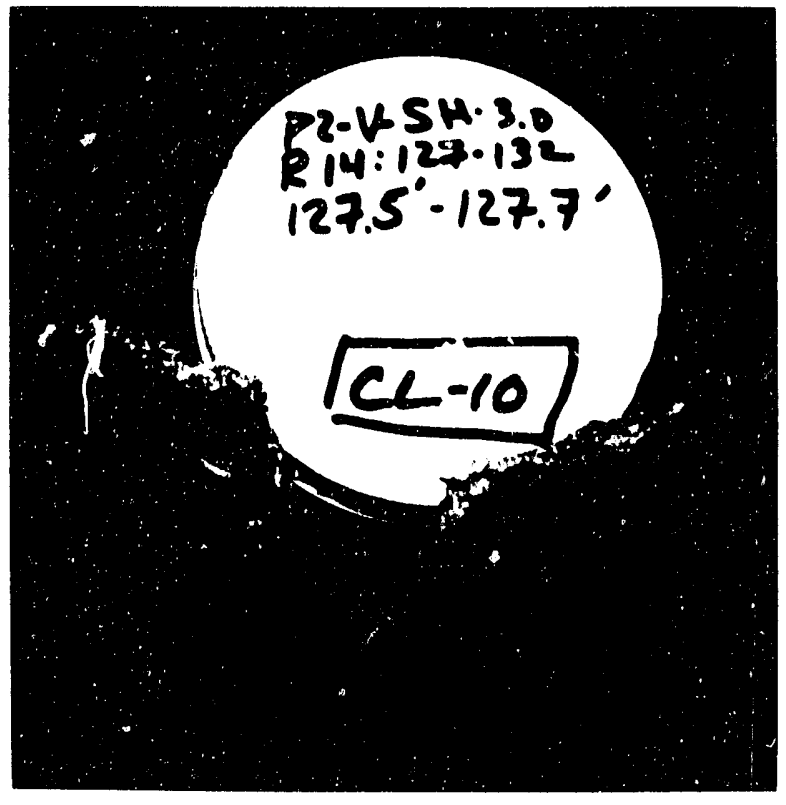

K-pica Core
Clavey sandstone teited positive for
cos

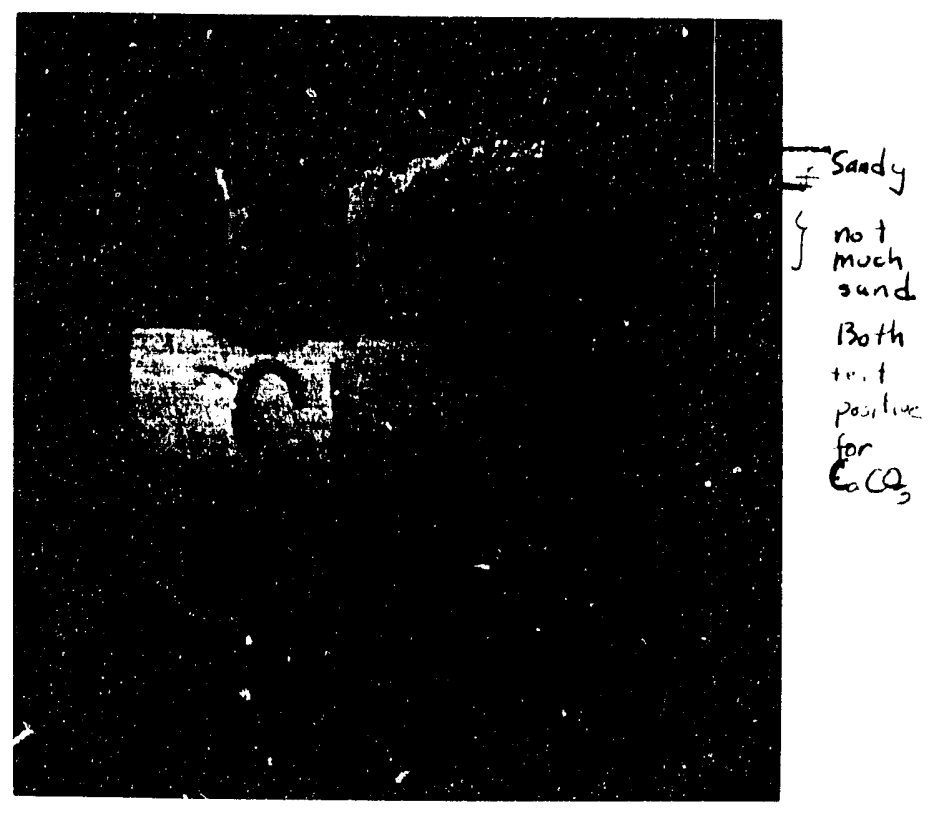

Krosea Core
Sanded $\rightarrow$ Gruut

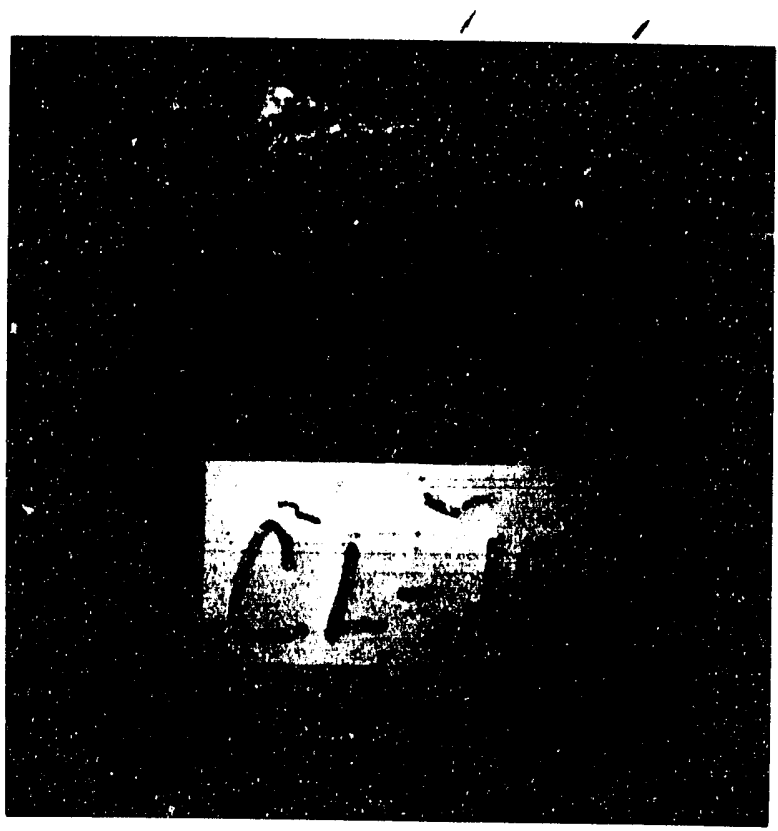

$\leftarrow$ Nout Grout

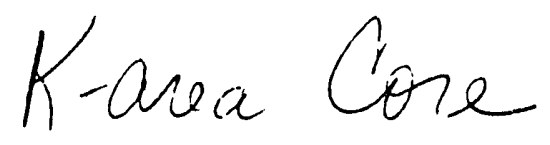




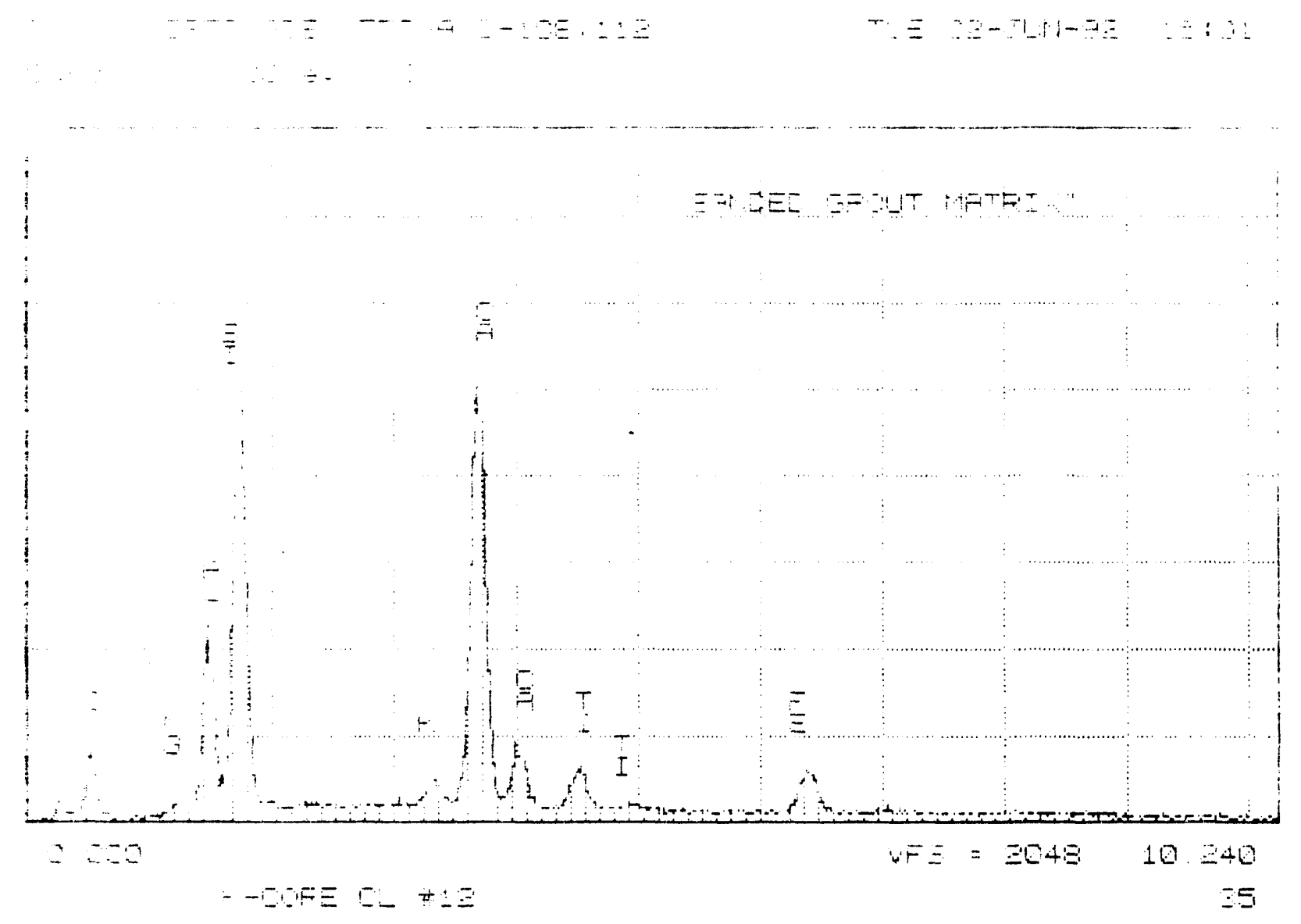

p. 四 3 
<smiles>[AlH2]=C[AsH2]</smiles> 

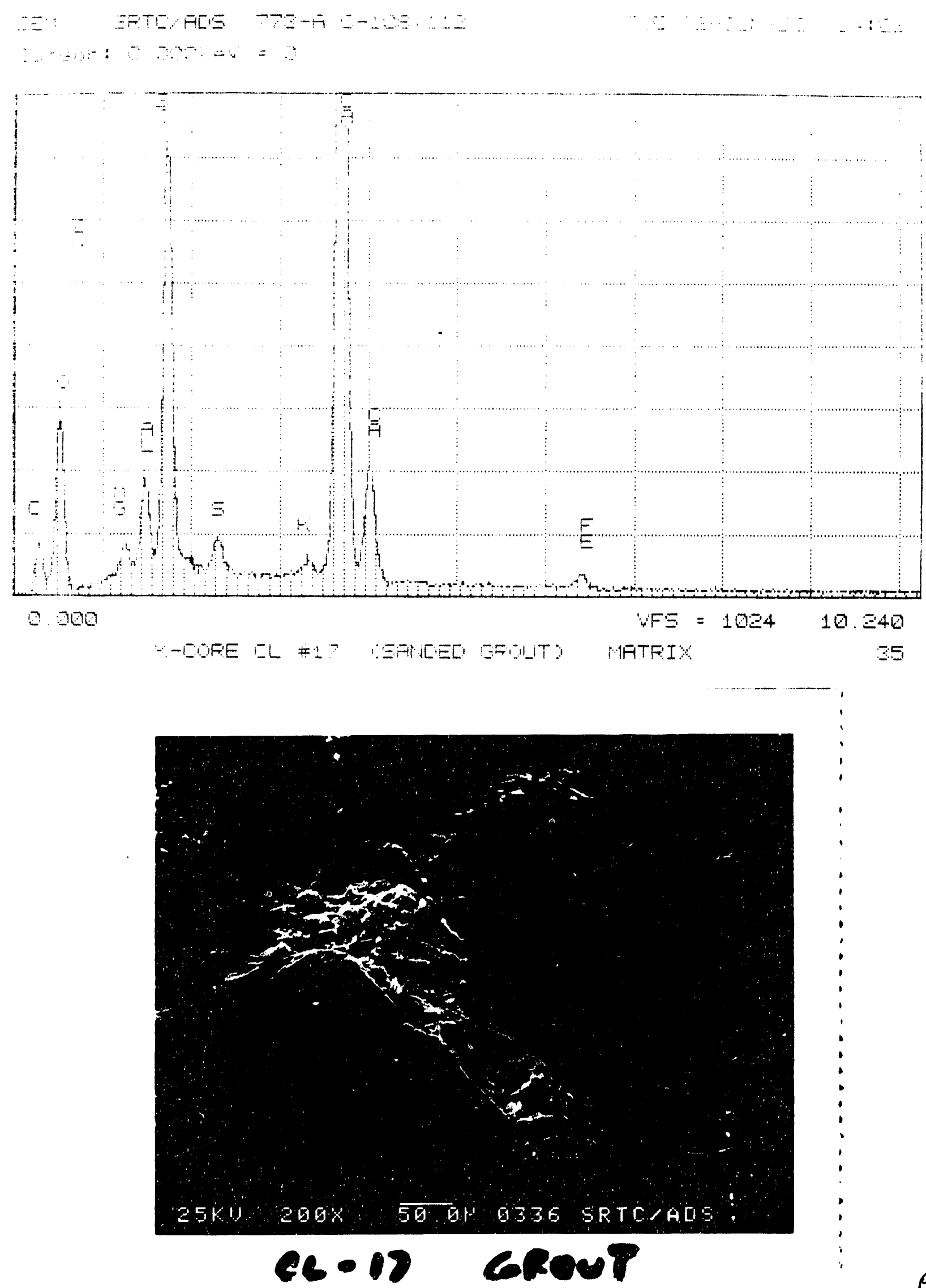

p. 且 4 

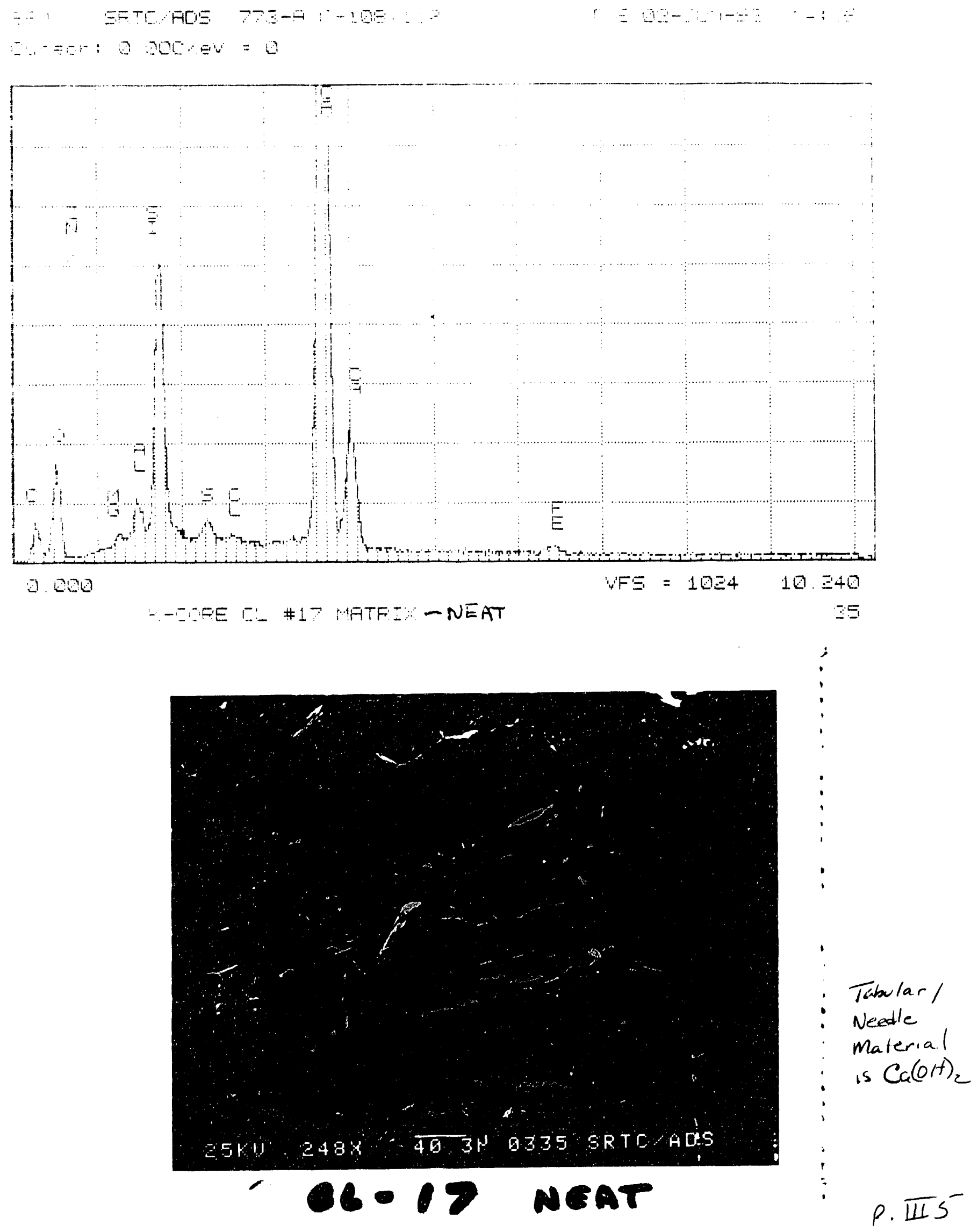
APPENDIX IV

Scanning Electron Microscope Secondary Images of R-Area Core with Energy Dispersive X-Ray Spectra of Selected Regions 


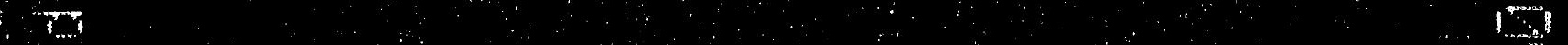


APPENDIX $\quad v$

X-Ray Diffraction Powder Pattern Charts of R-Area Samples 


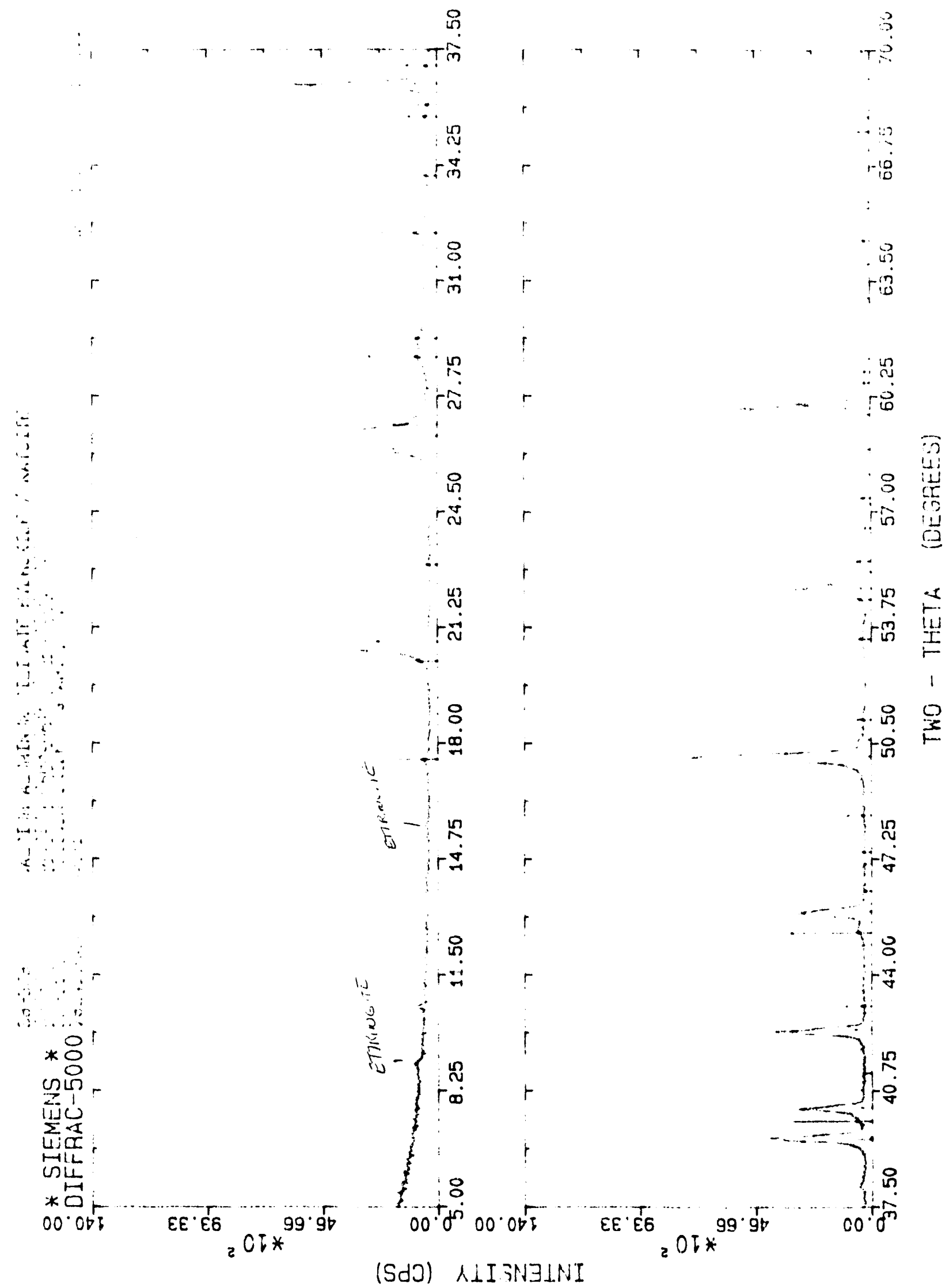

P. Appendix 


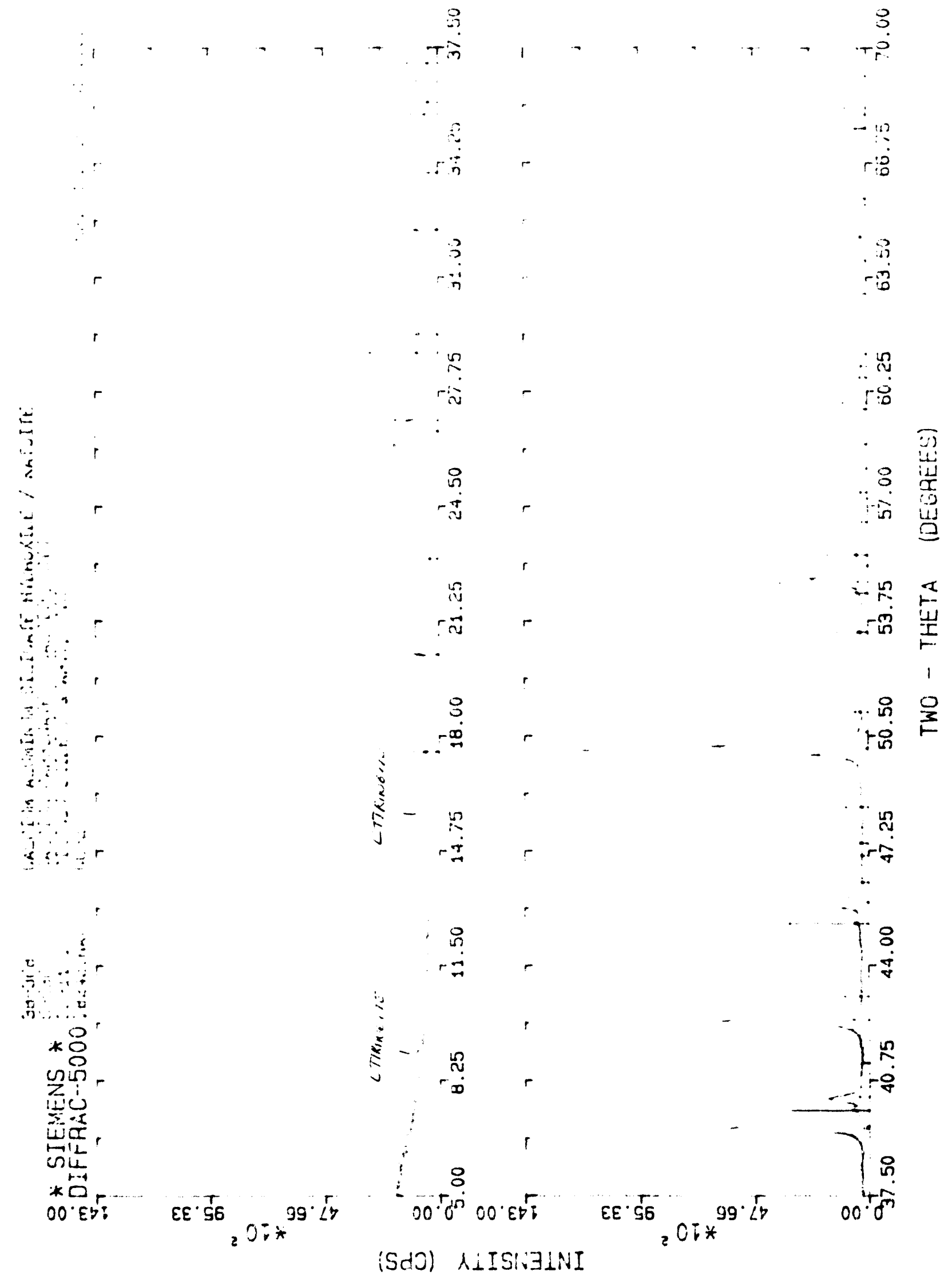




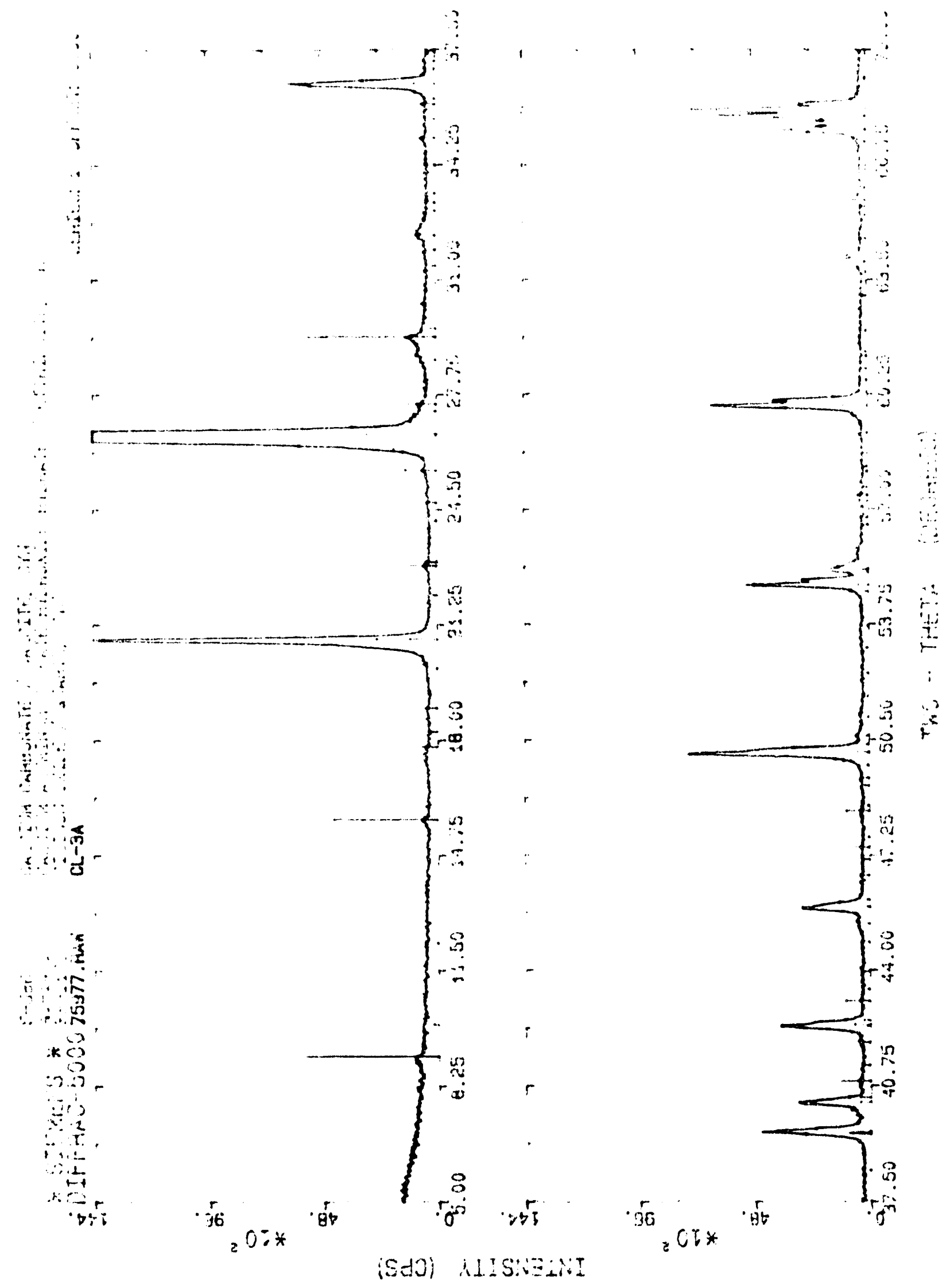

P. I -3 


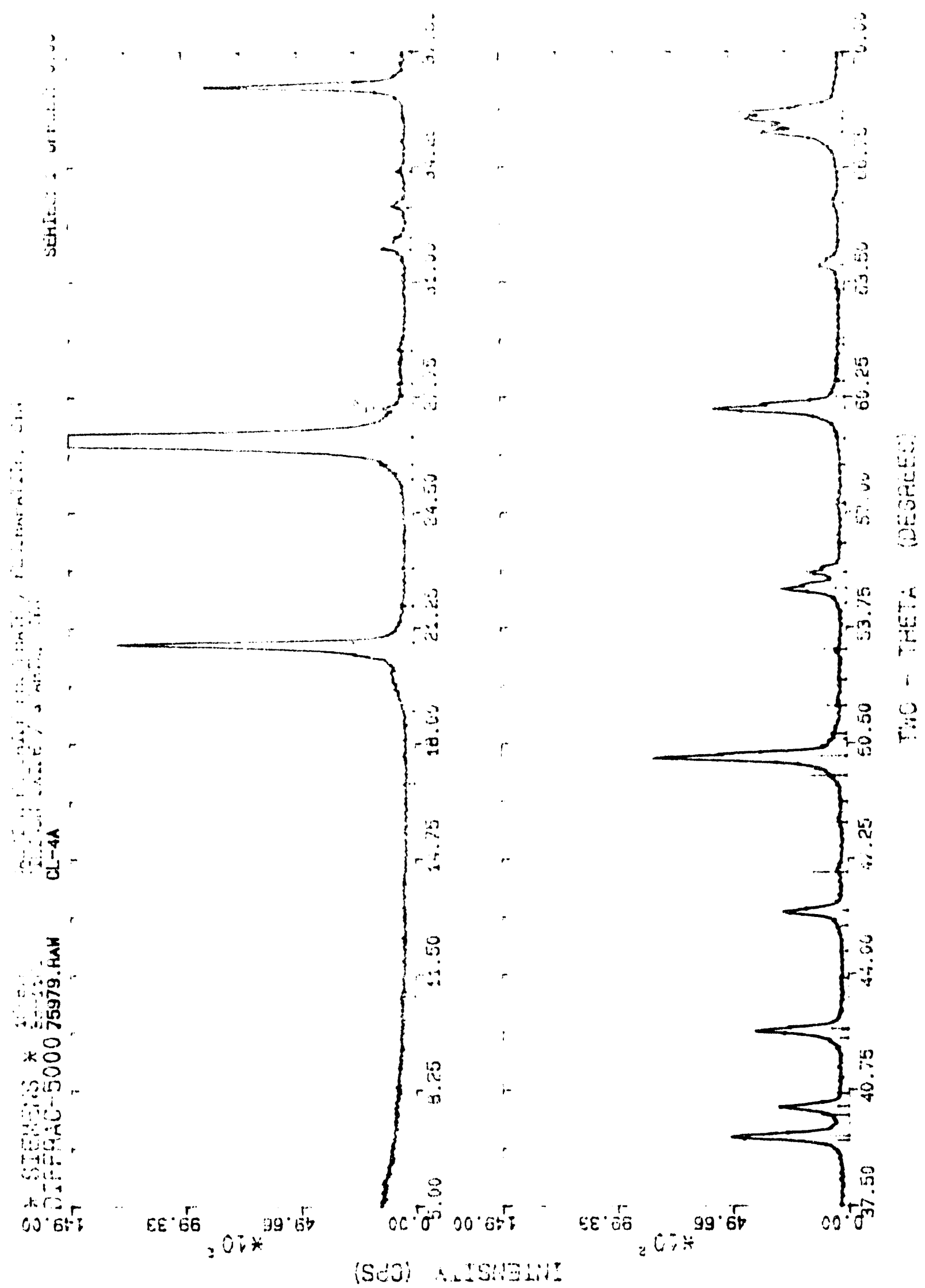

p. II-4 


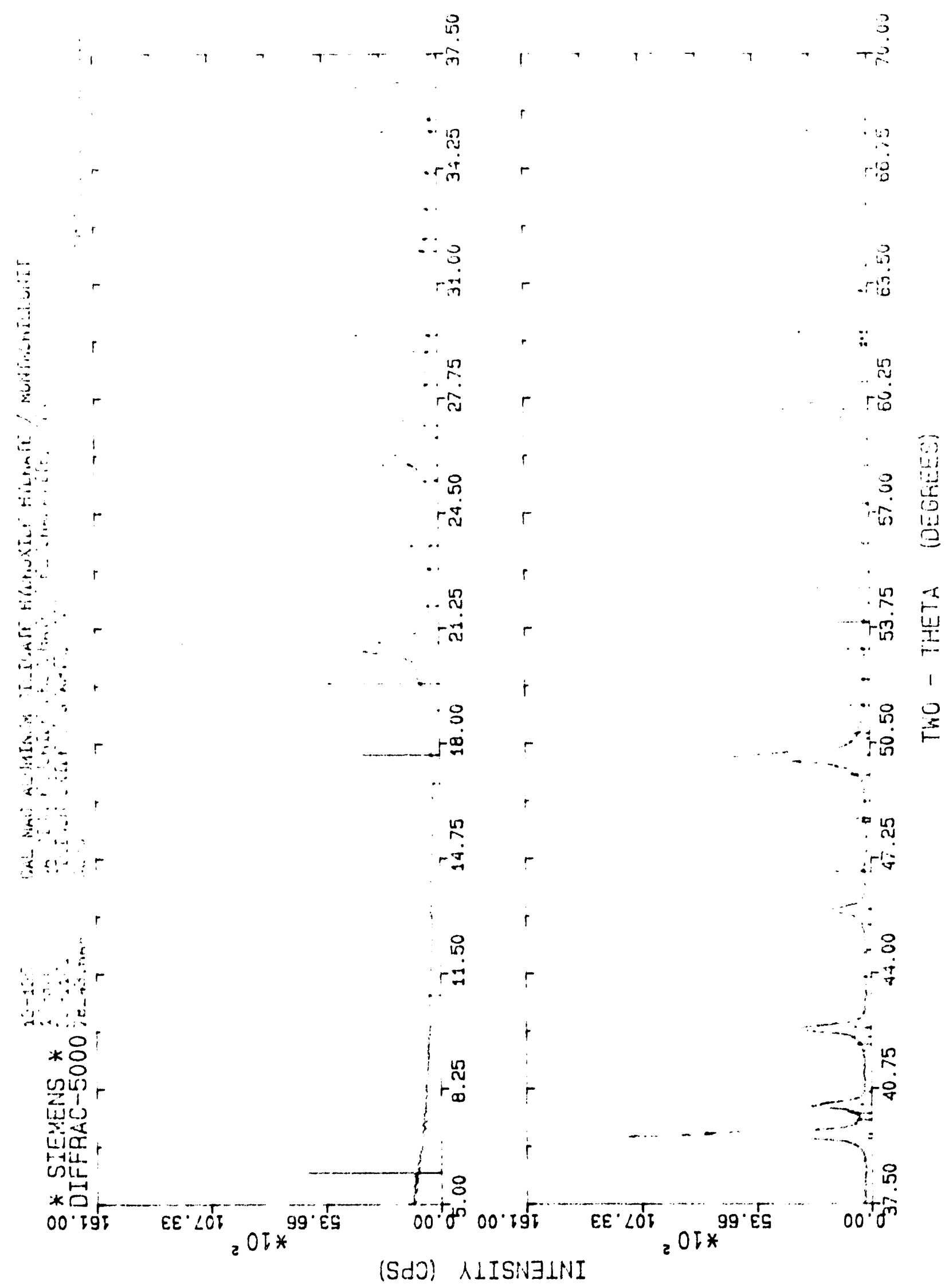

P. $I-5$ 


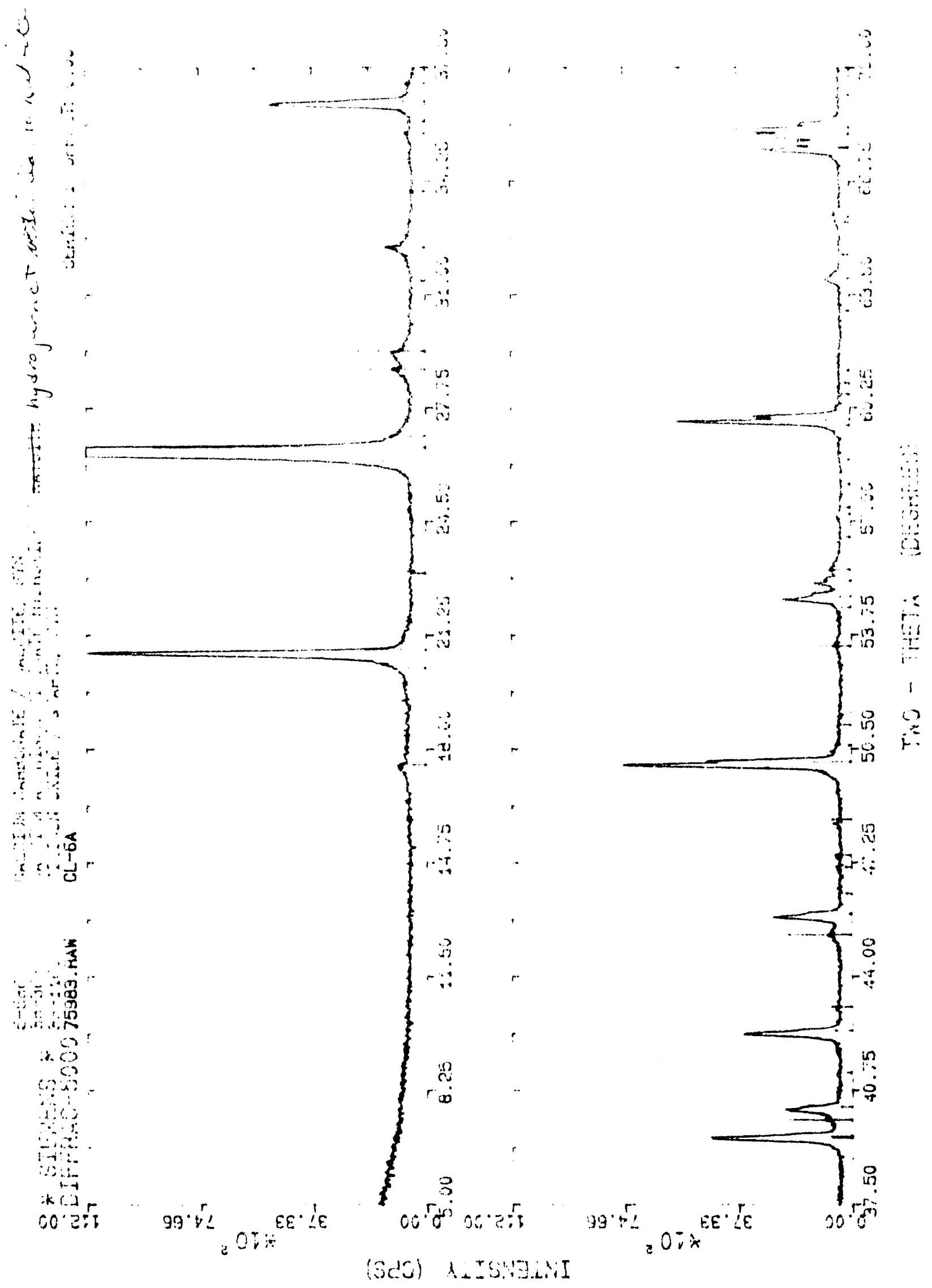

p. $\bar{Z}-6$ 


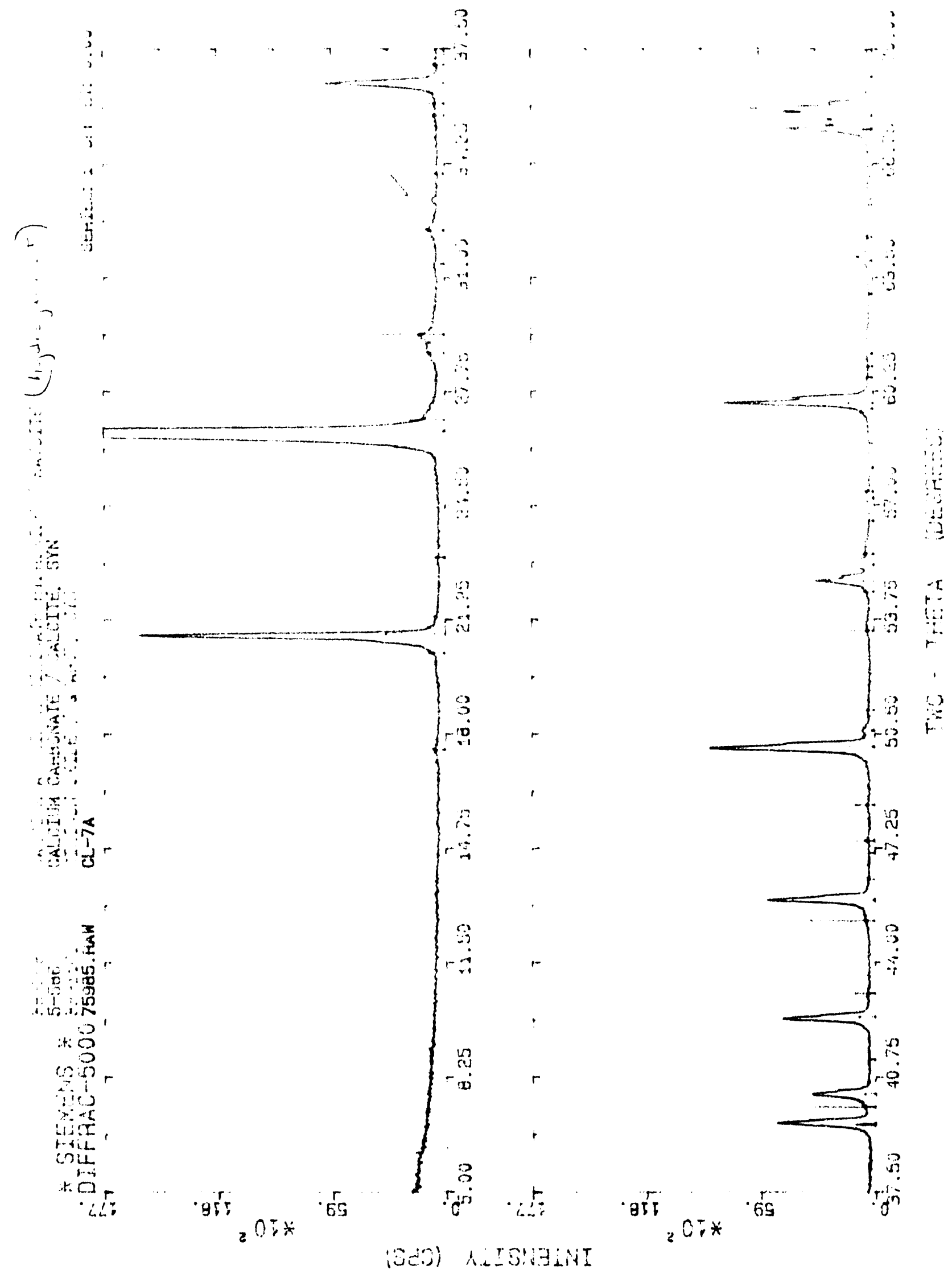




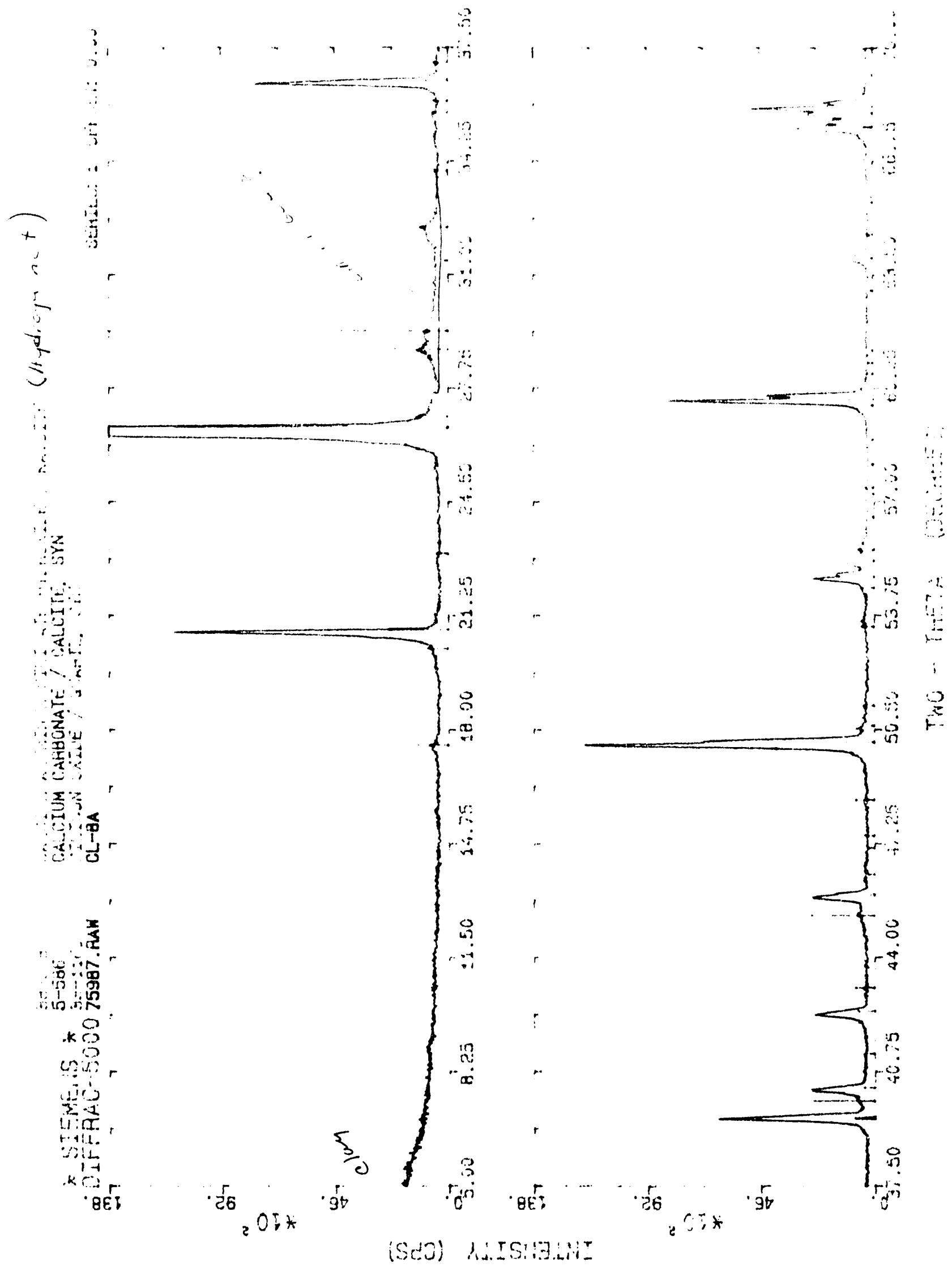




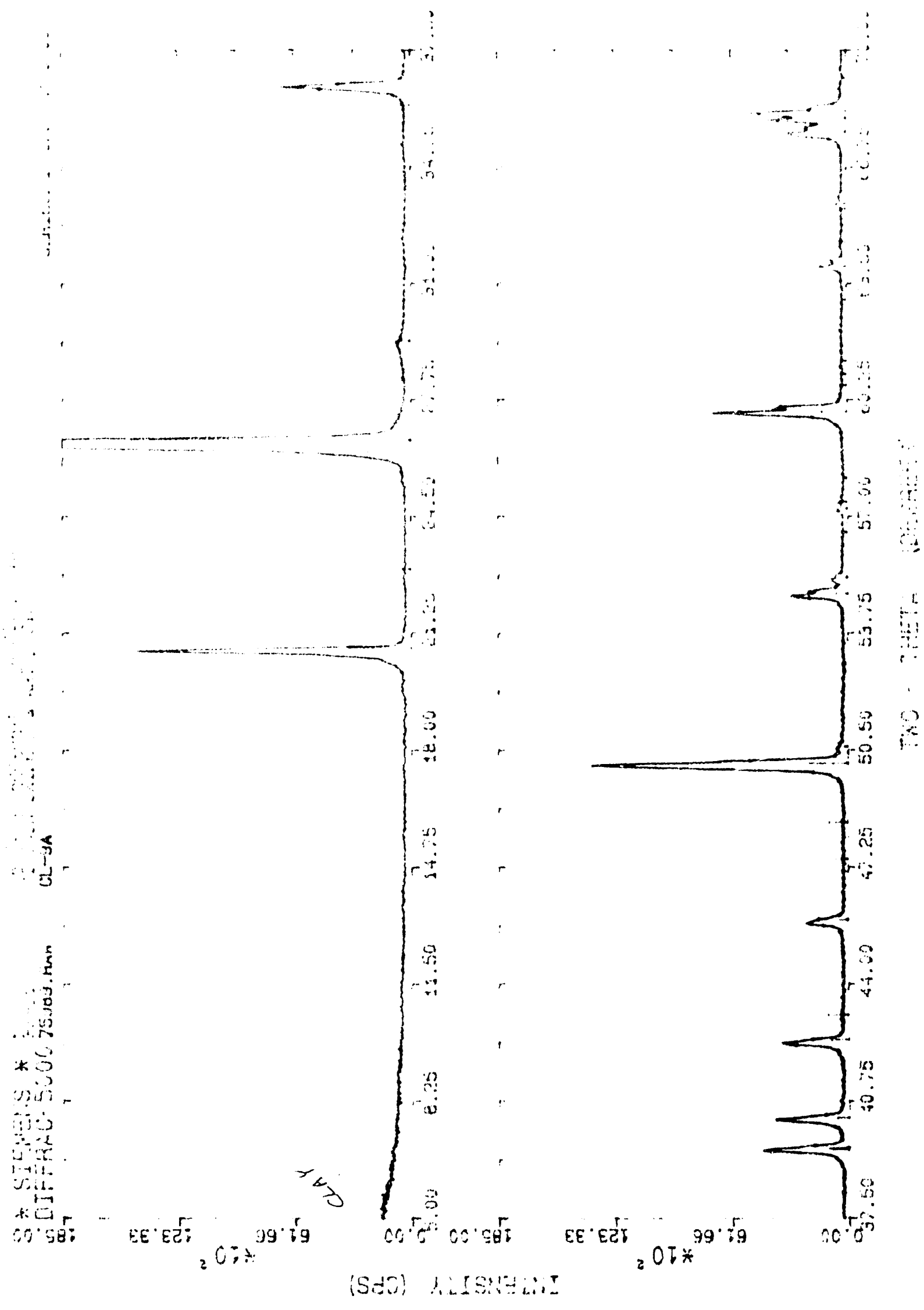




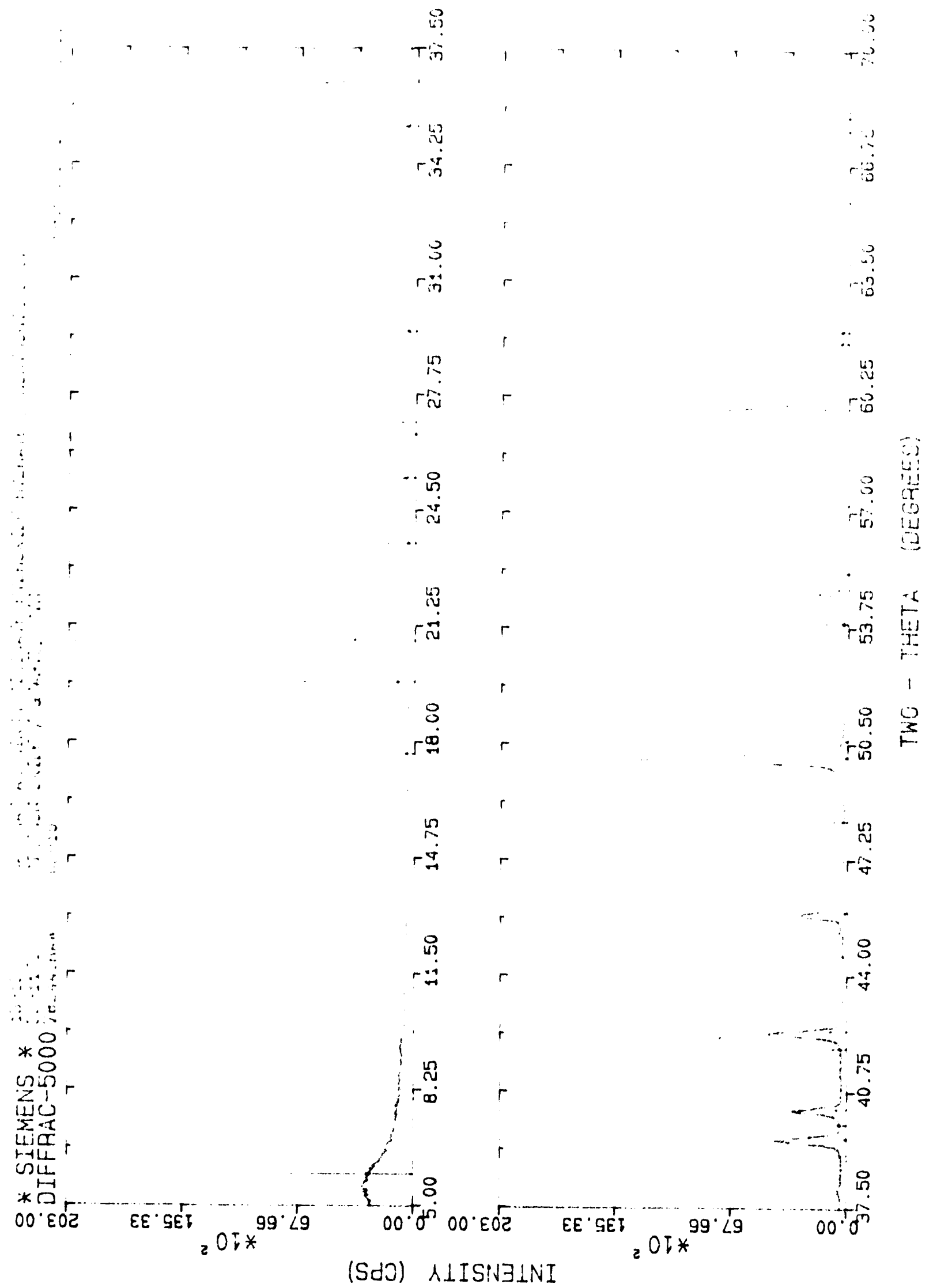




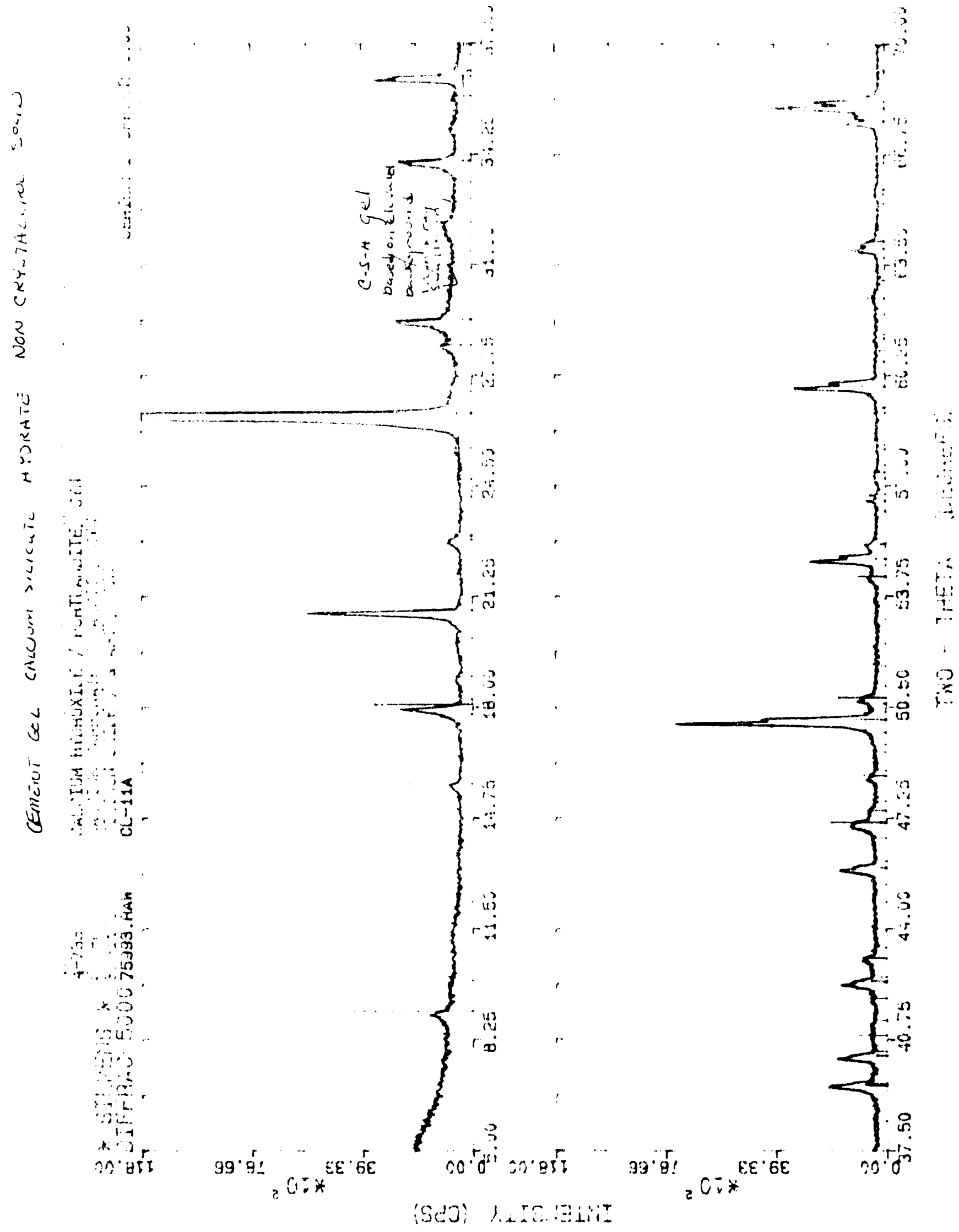




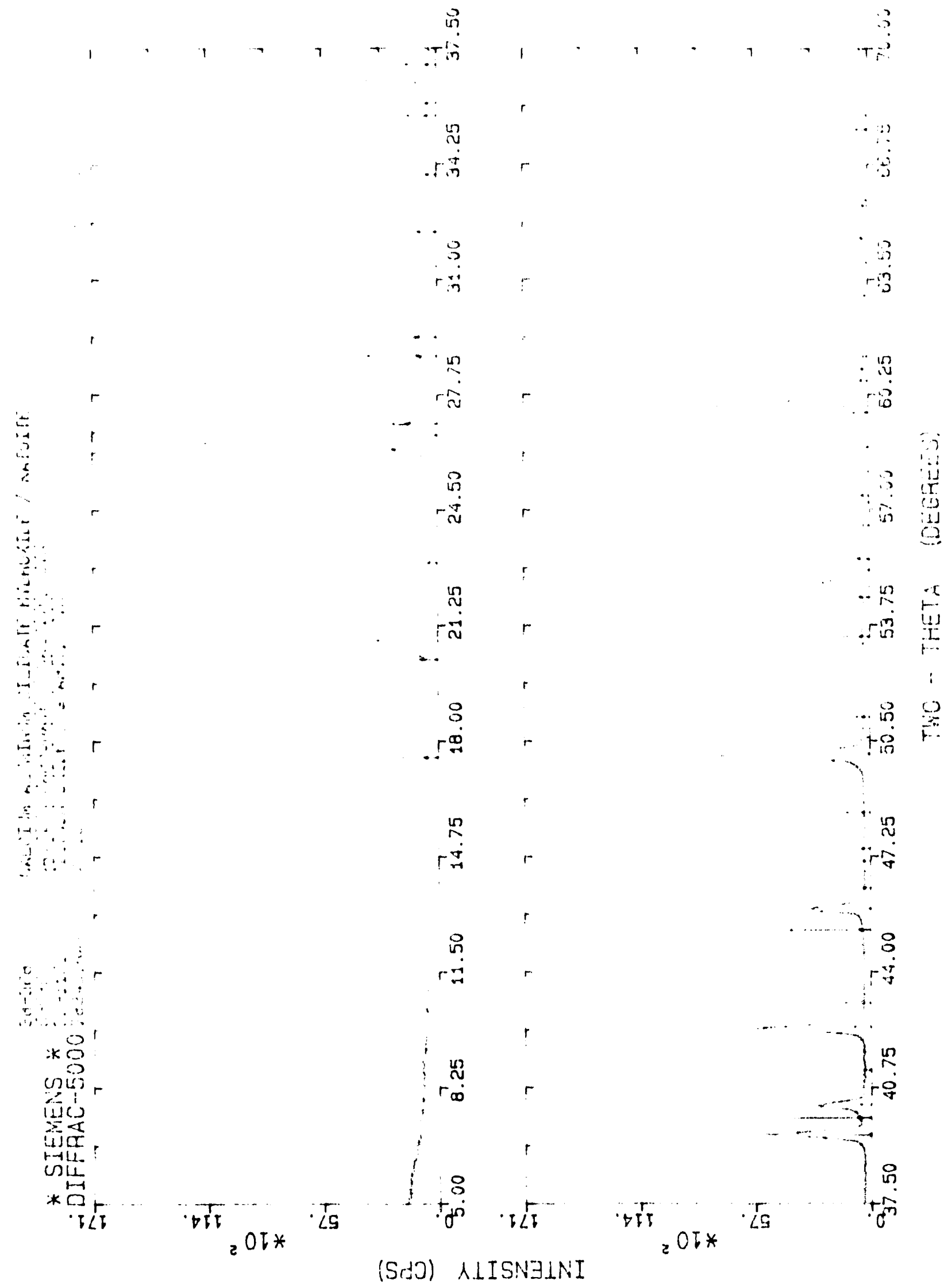

p. I / 


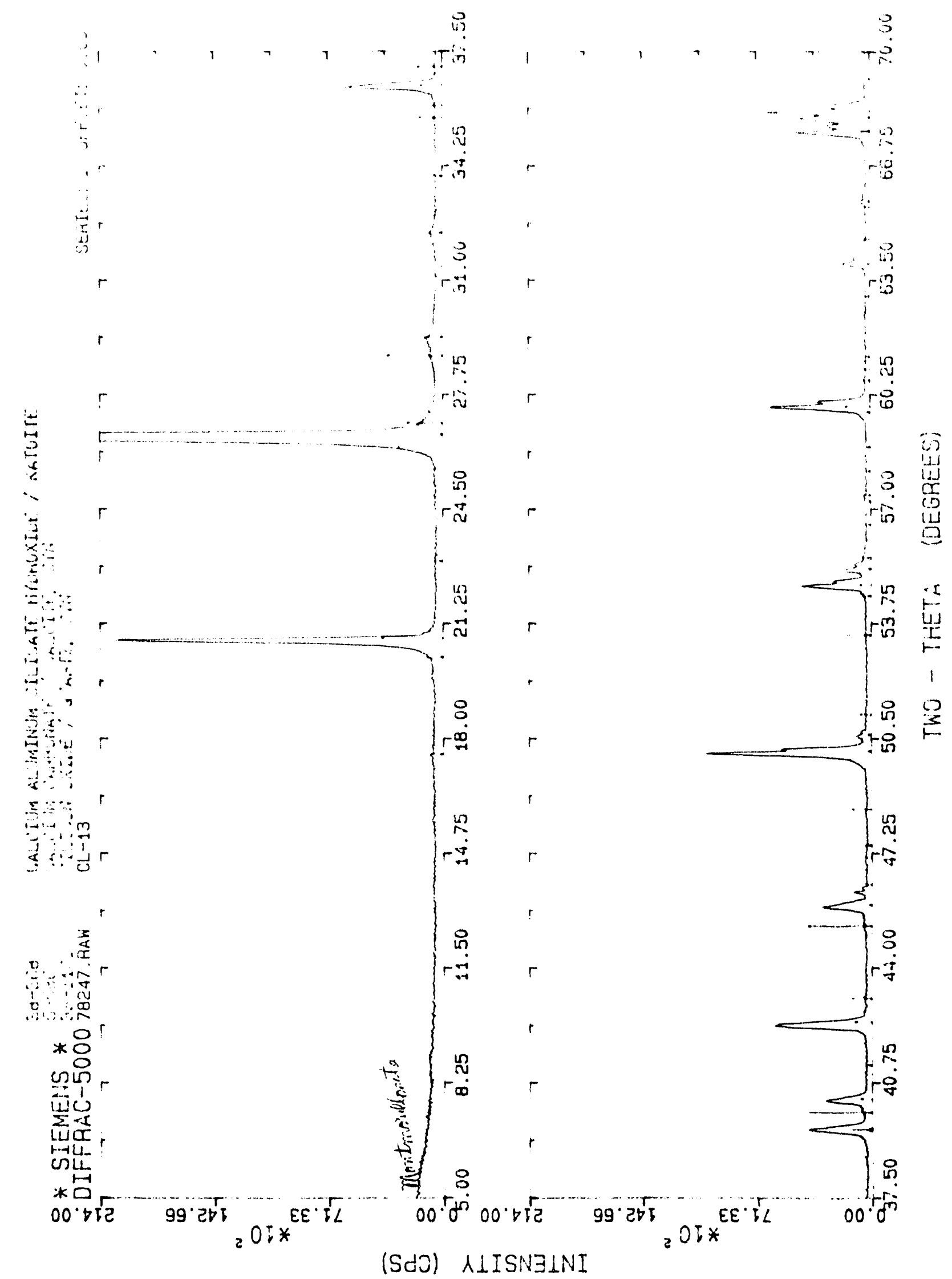

p.I 13 


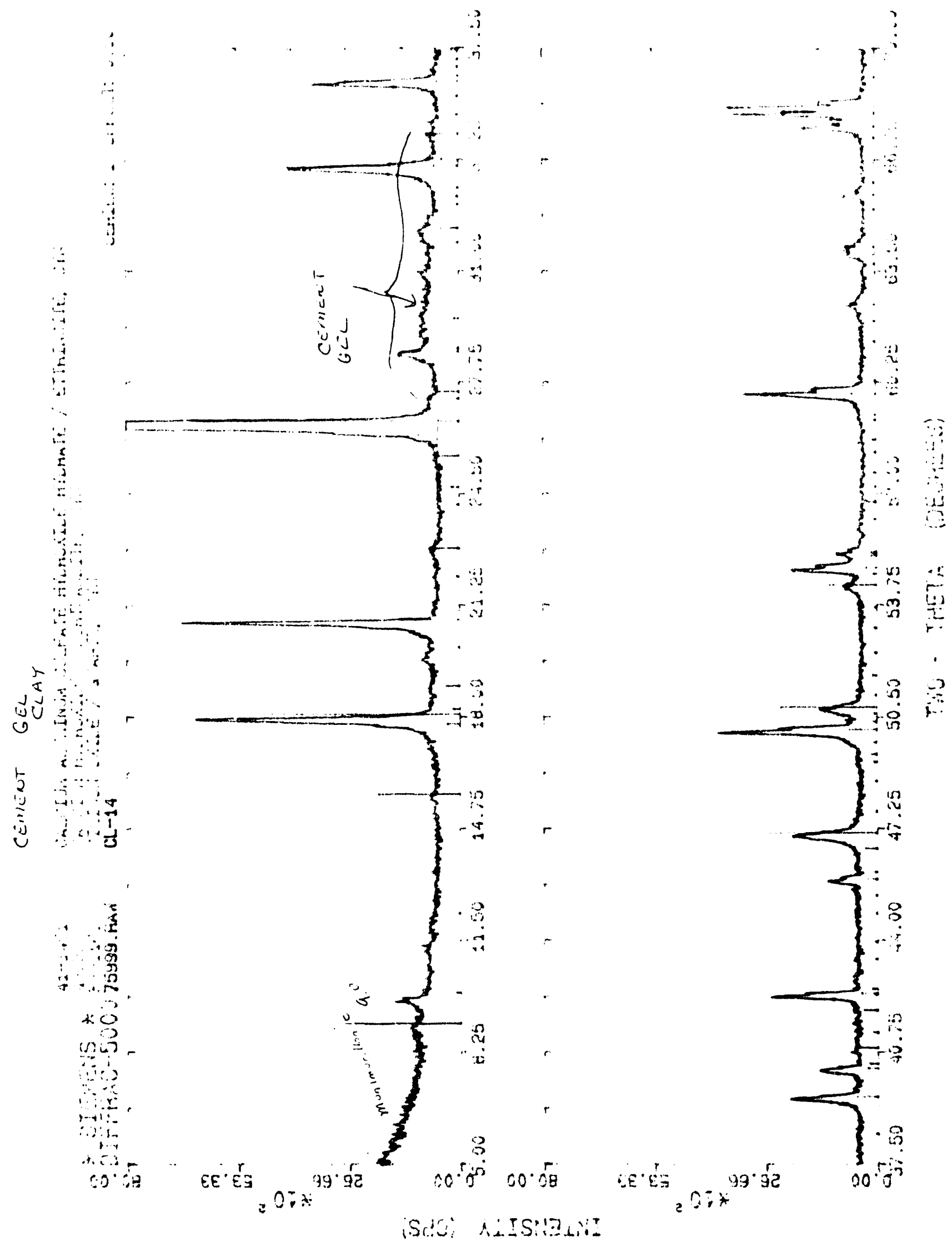




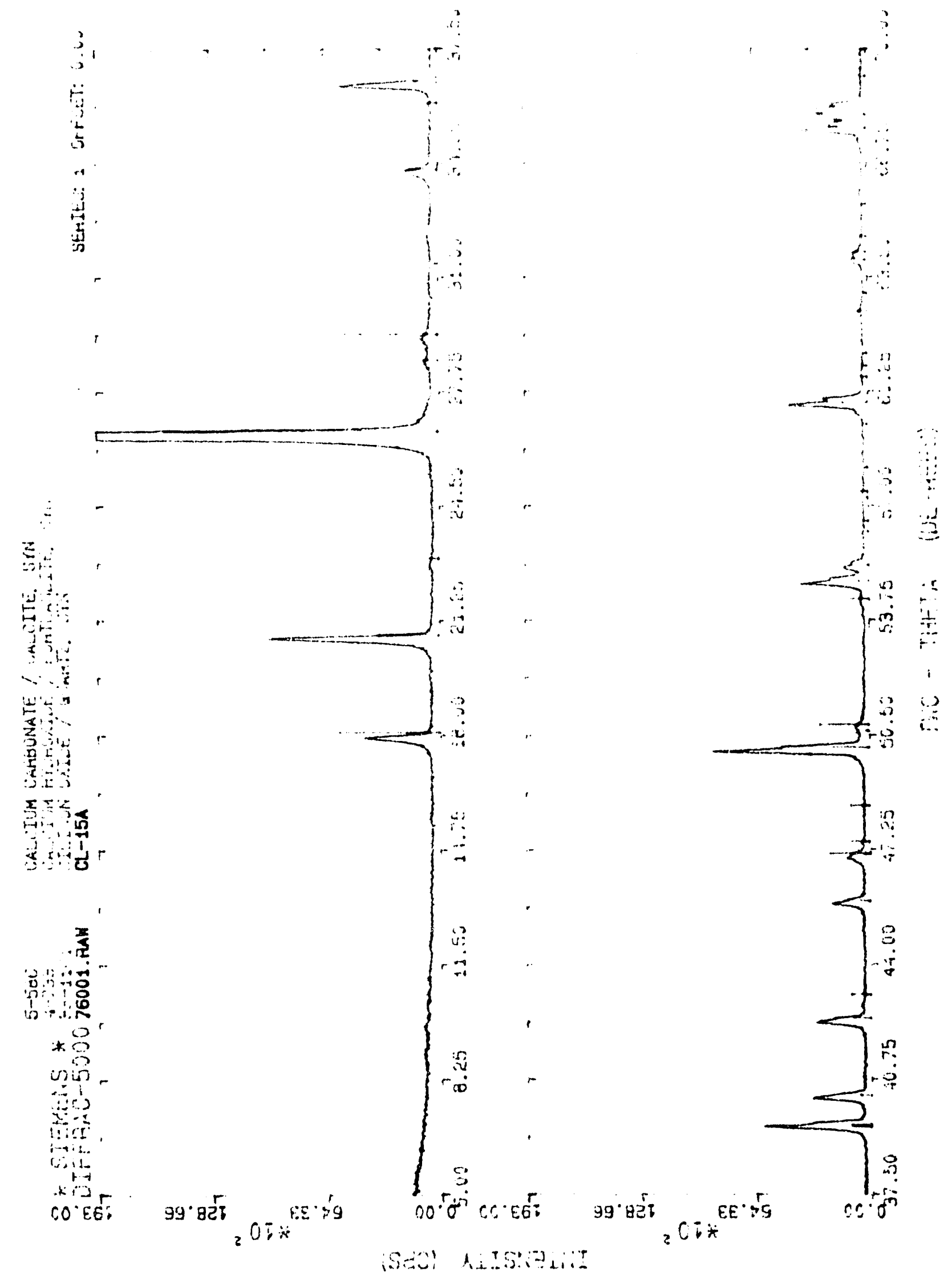

p. I 15 
- $\div$

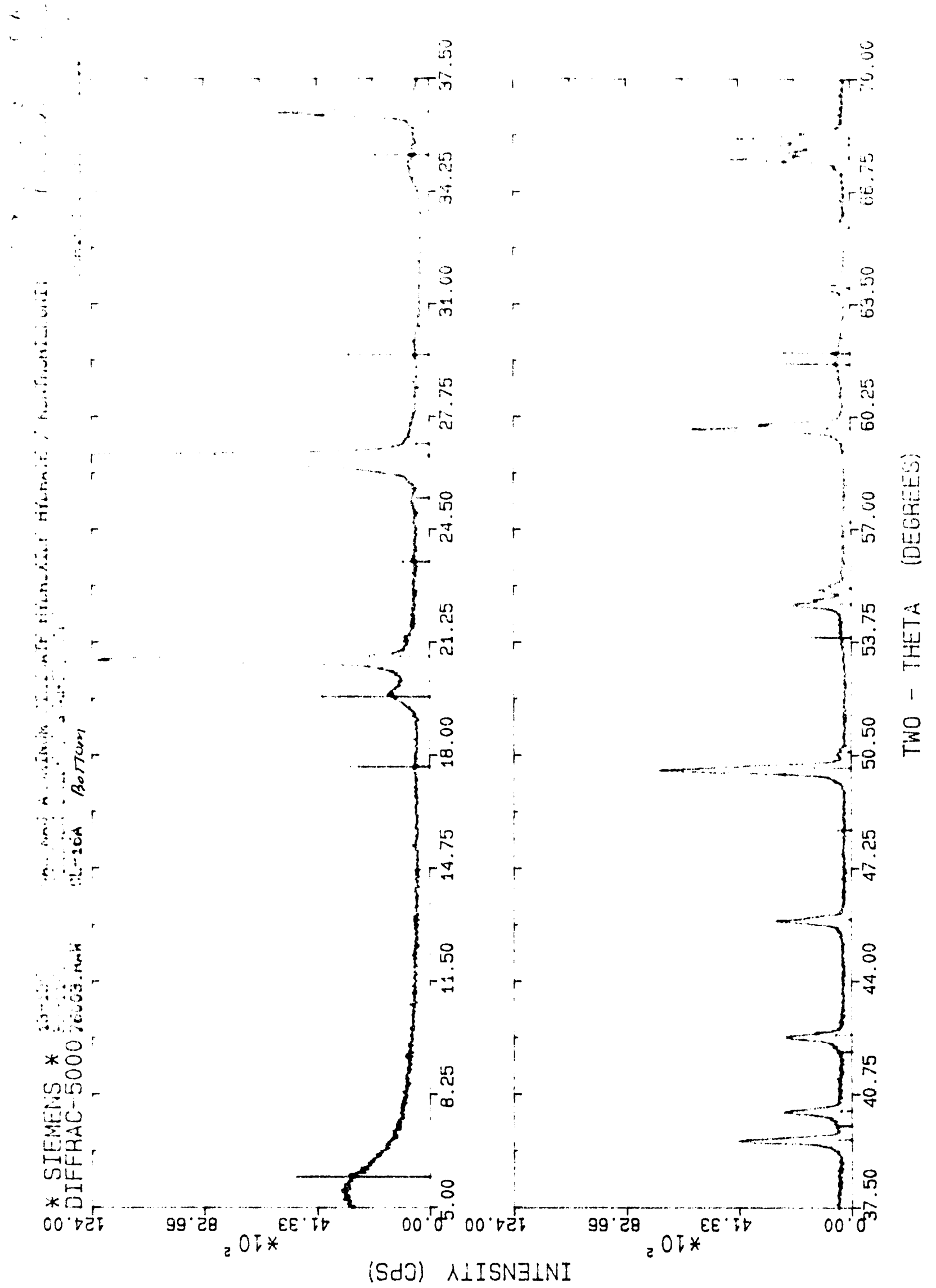




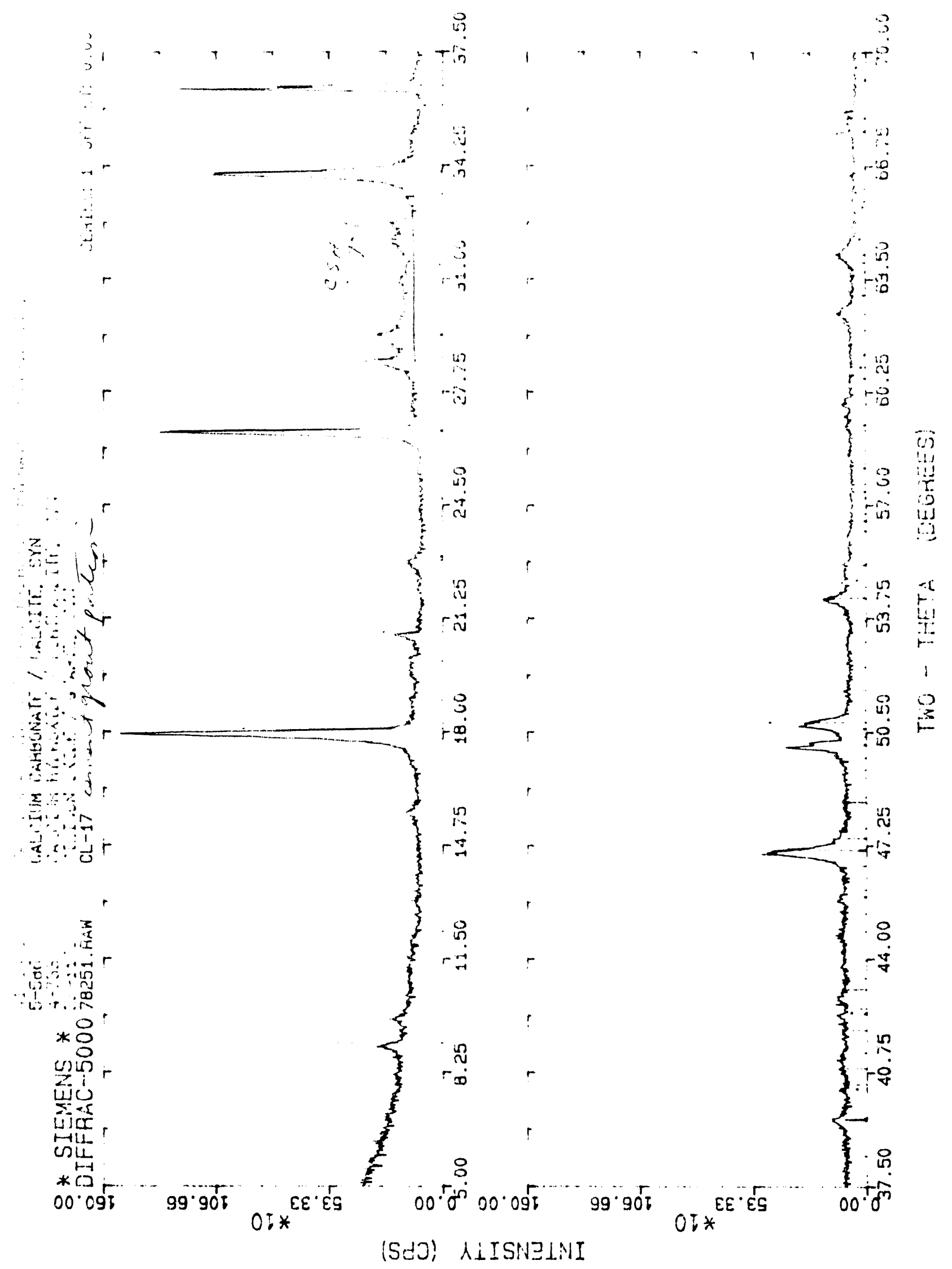

$p \cdot \bar{L}, 7$ 


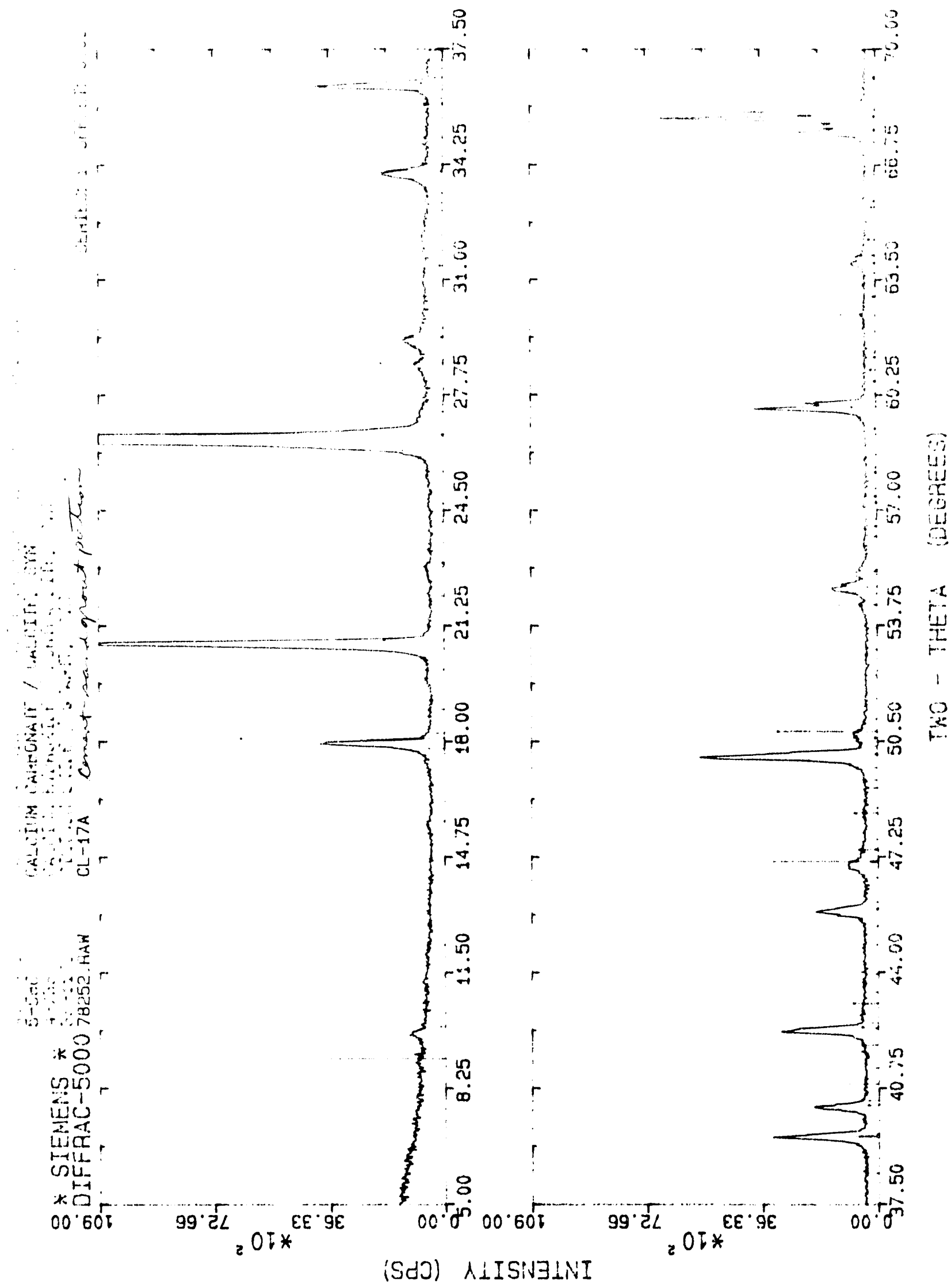



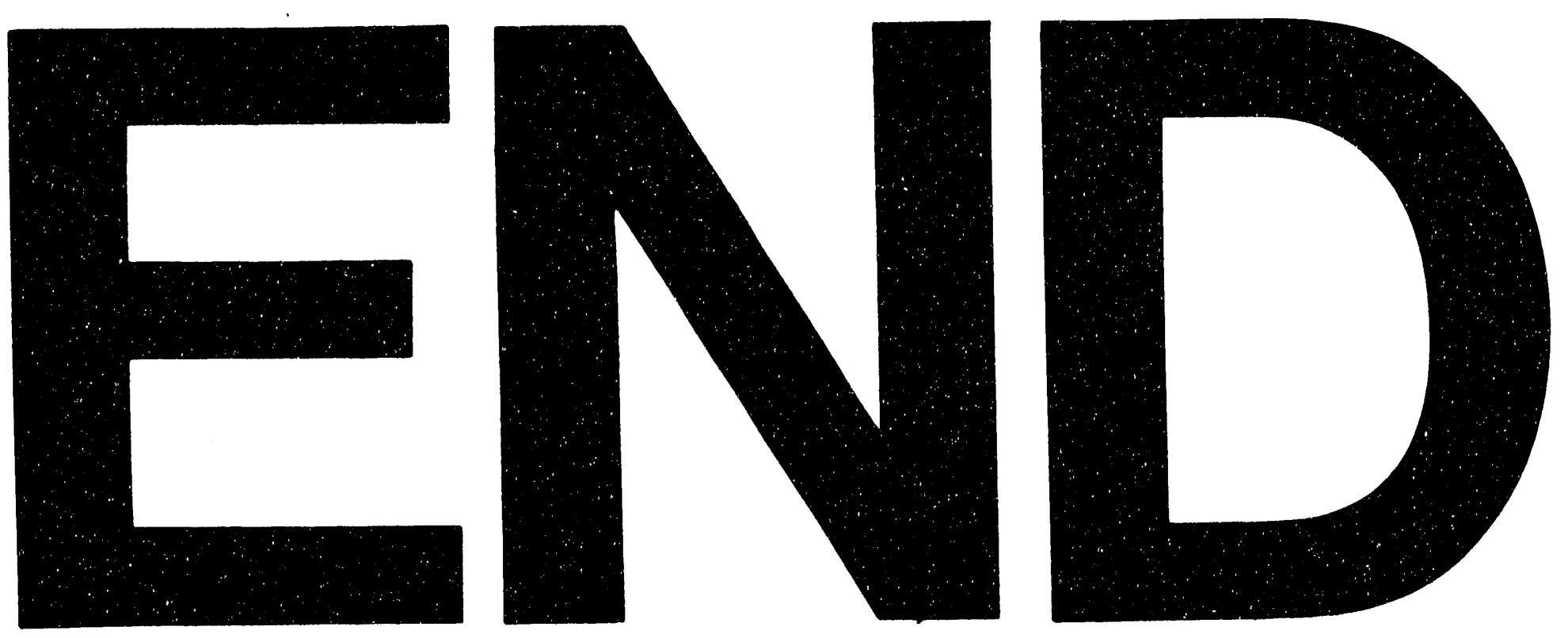

1

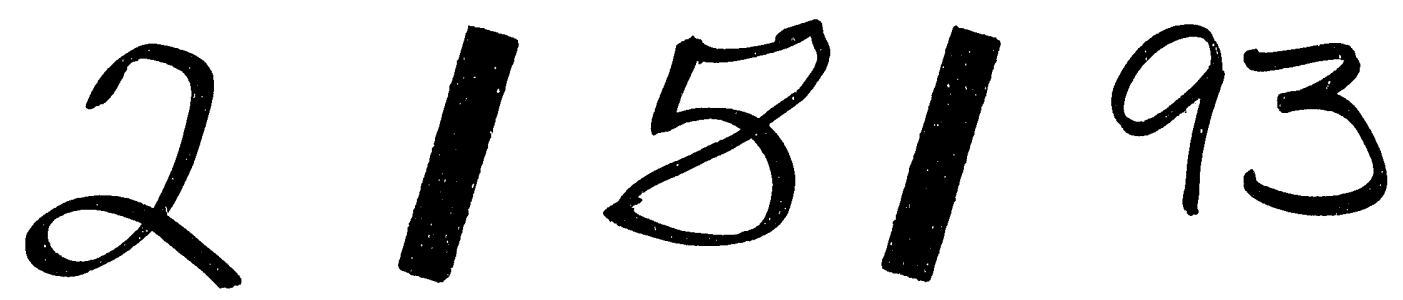


